\title{
مقومات التعايش في الثريعة الاسلامية وأثرها في بث روح التسامح الايني ونبذ التطرف
}

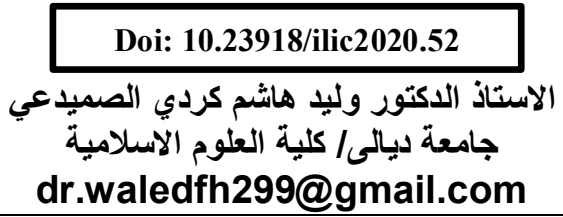

\section{بسم الله الرحمن الرحيم

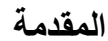

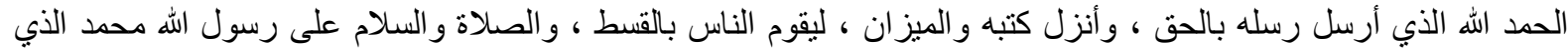

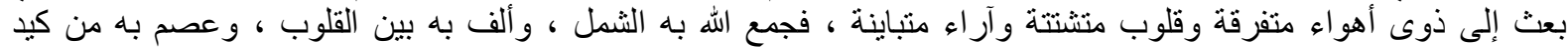

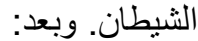
فإن الإسلام جاء في فترة جاهلية أهدرت كر امة الإنسان وحريته فأعاد الإسلام بناء الإنسان من جديد ونظم علاقته بربه و علاقته

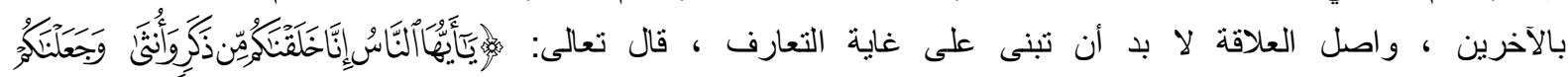

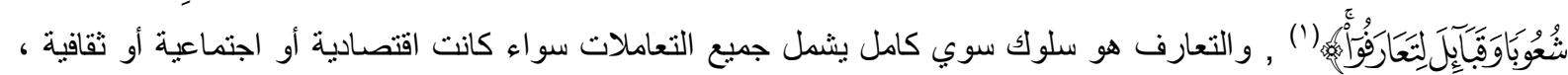

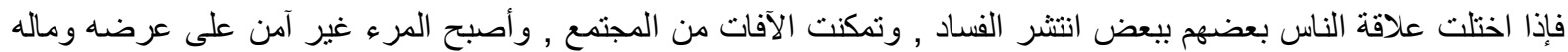

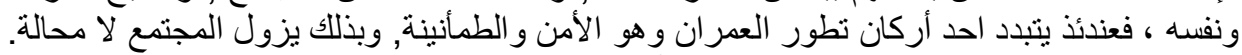

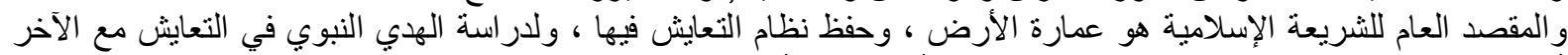

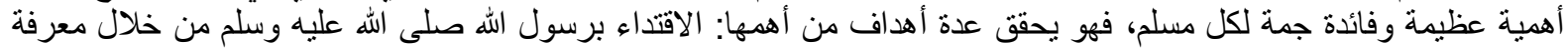
تعامله مع غير المسلمين ، وتكسب المسلم و غير المسلم محبة الرسول صلى الله عليه وسلم وتتميها وتباركها، و على هذا فكل مسلم

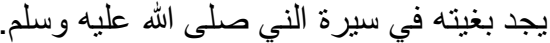
لذا ارتأيت أن يكون عنوان بحثنا (مقومات التعايش في الثريعة الاسلامية وأثرها في بث الثئ روح التسامح الديني ونبذ التطرف ) ) ، و الذي دعانا للكتابة في هذا الموضوع ما نجده في زماننا هذا الذي كثر فيه الإفر اط و التفريط ، وقل من يسلك فيه طرئ طريق الوسط

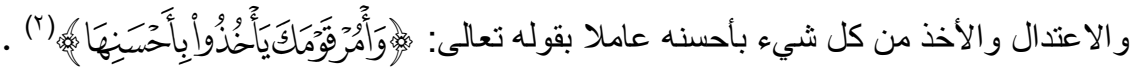
وقد جاء البحث مقسما على مقدمة ومبحثثين وخاتمة.

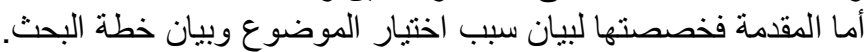

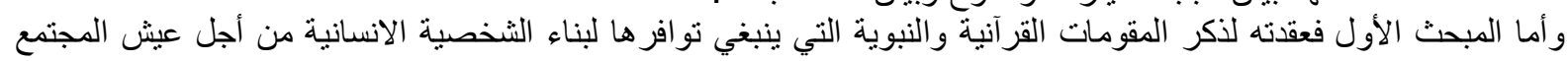
بسلام. و أما المبحث الثاني فذكرت فيه صورا من تعايش وسماحة النبي صلى الله عليه وسلم وإحسانه مع غير المسلمين. وأما الخاتمة فضمنتها النتائج التي توصلت التهان إليها في البحث. و الله هو المسئول أن يؤلف بين قلوبنا لتو ، ويصلح ذات بينتا، ويهدينا سبل السلام. تمهيد:

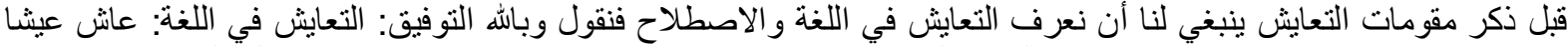

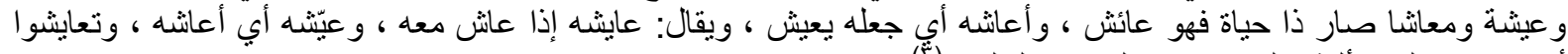

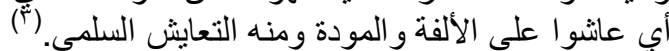

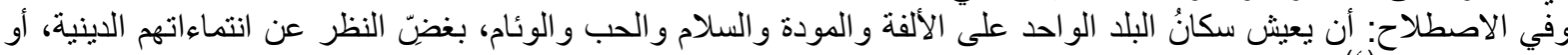
و التعايش الذي نعنيه ليس المقصود منه أن نذيب الدين الإسلامي في بقية الأديان ، ولكن التعايش هو كيف نتعايش بما يحترم كل

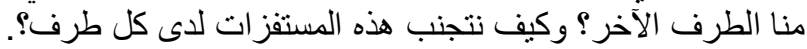

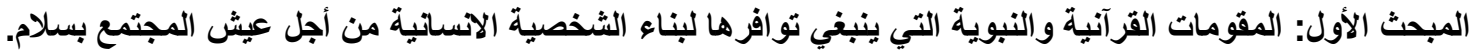

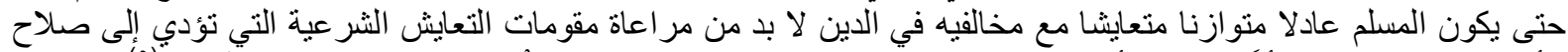

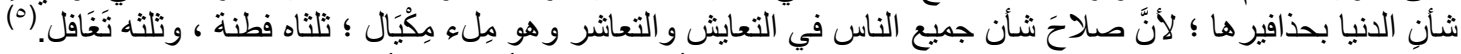

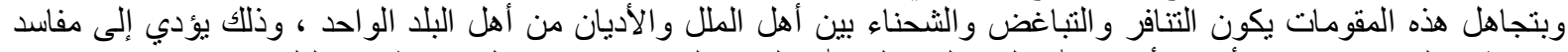

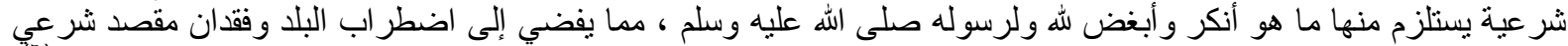

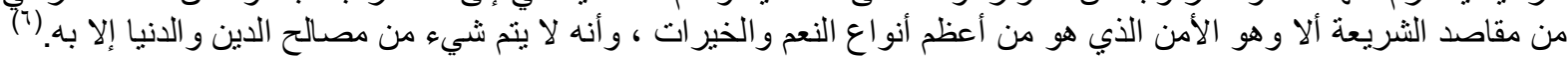

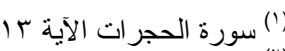

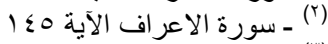

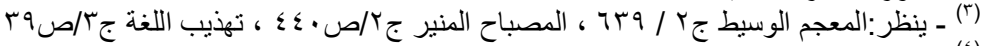

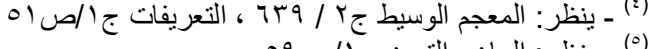

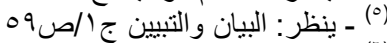

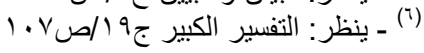


ومن أهم هذه المقومات ما يلي:

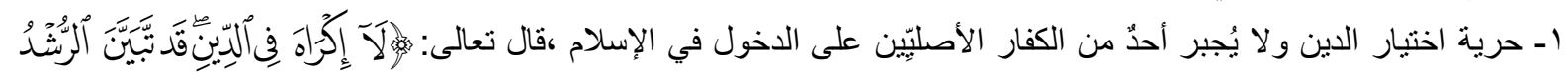

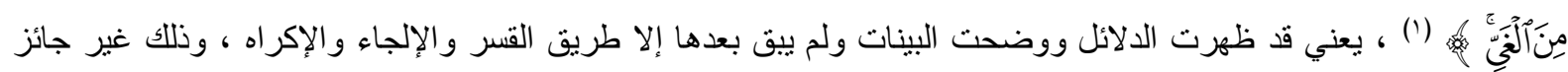

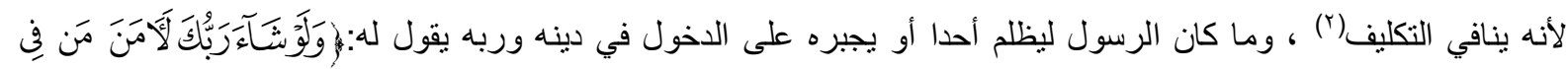

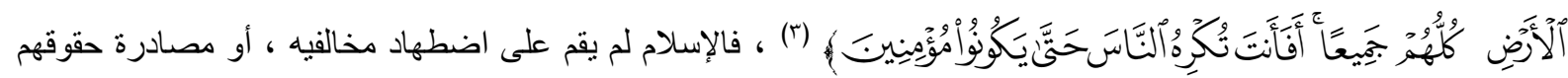

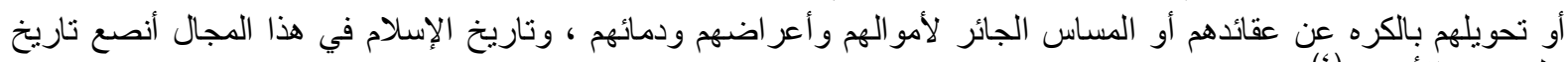

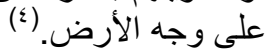

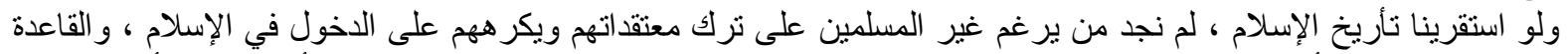

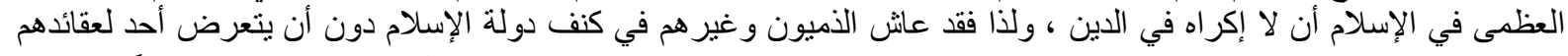

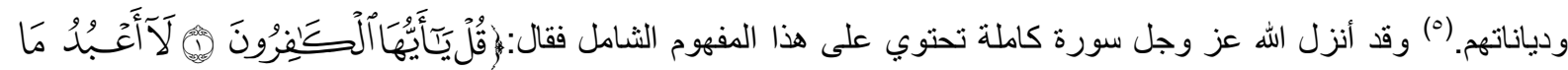

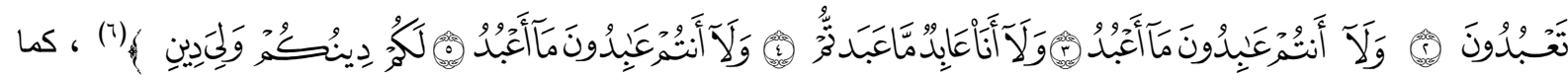

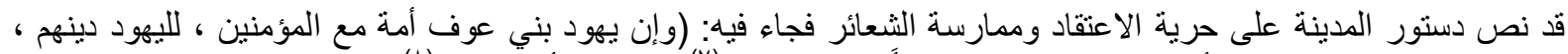

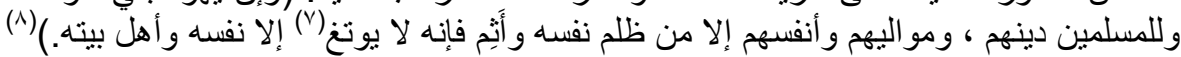

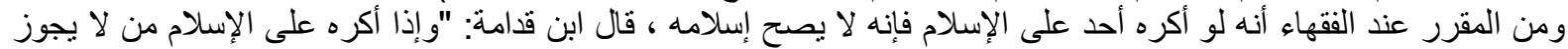

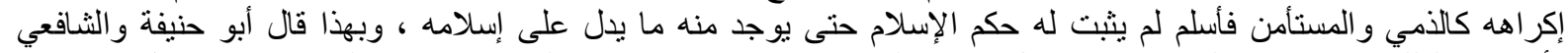

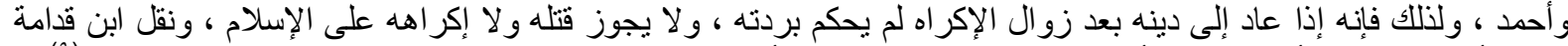

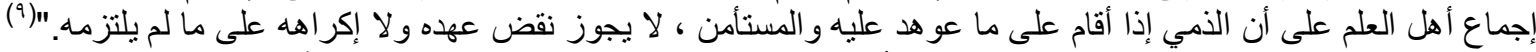

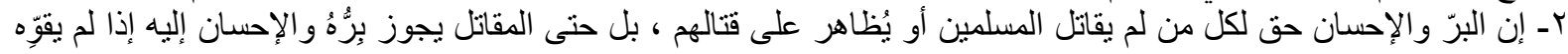

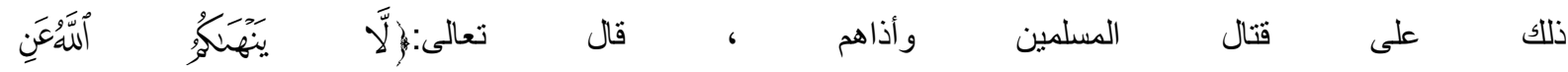

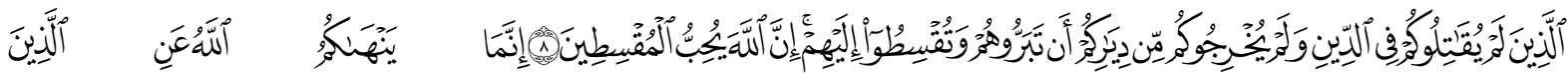

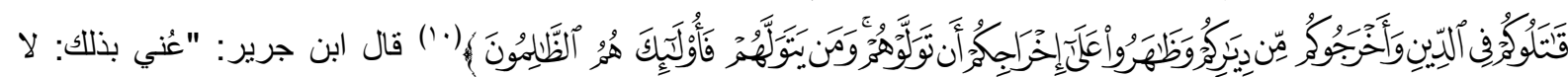

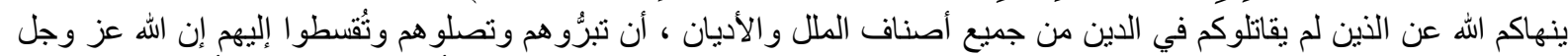

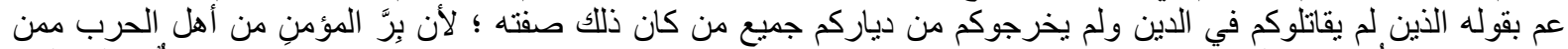

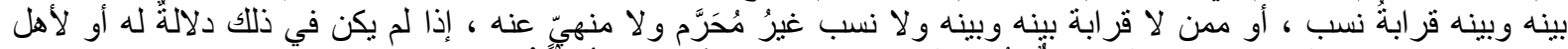

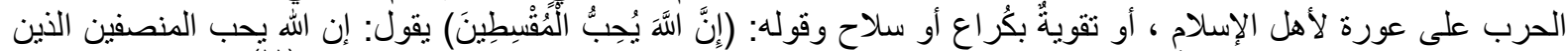

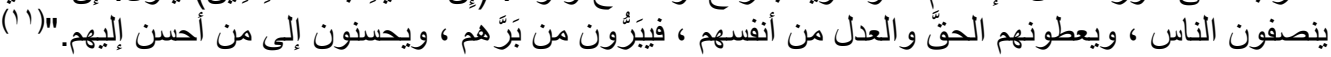

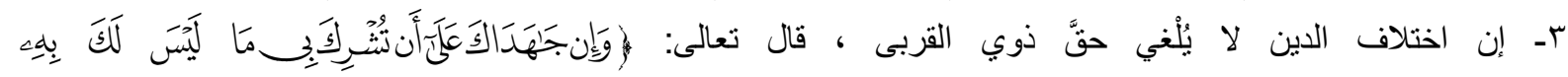

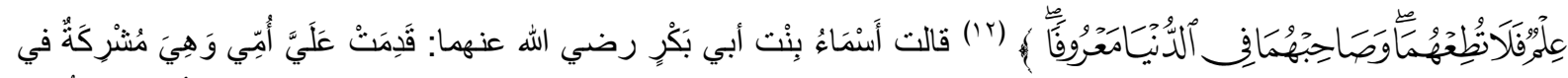

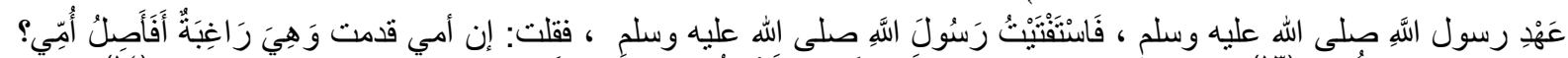

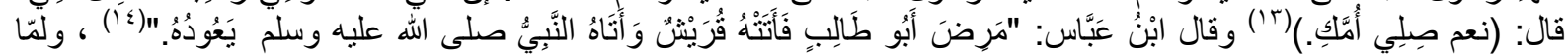

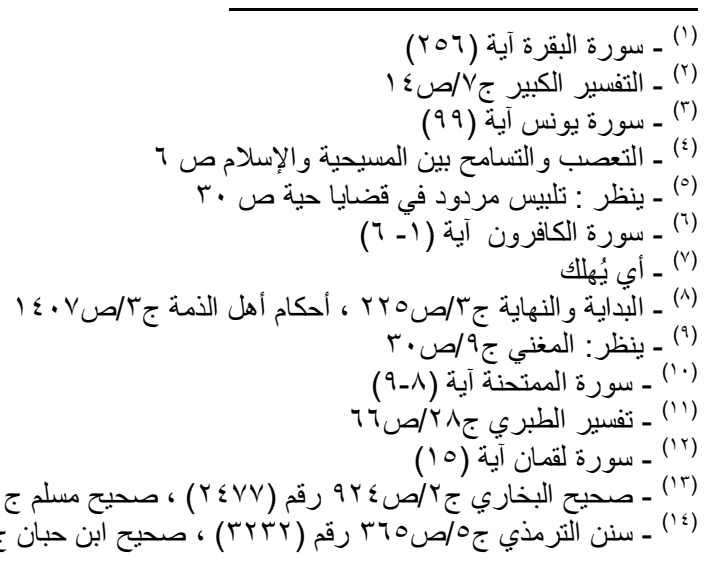


أهدى النبيٌُ صلى الله عليه وسلم عمر بن الخطاب رضي الله عنه حُلَّةَ ذاتِ قيمة ، أهداها عمر رضي الله عنه أخًا له بمكة كان

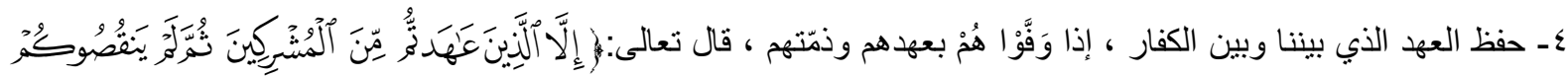

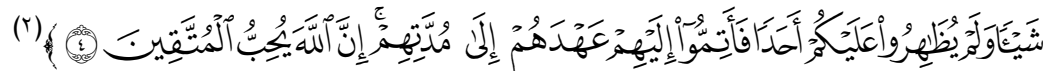

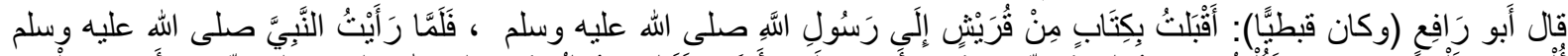

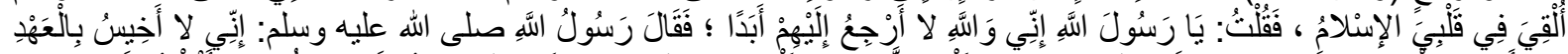

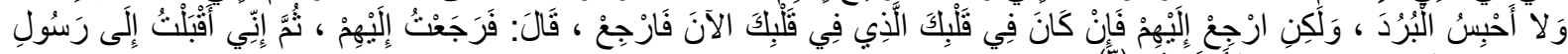

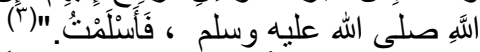

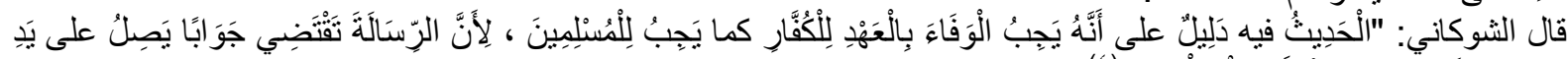

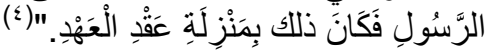

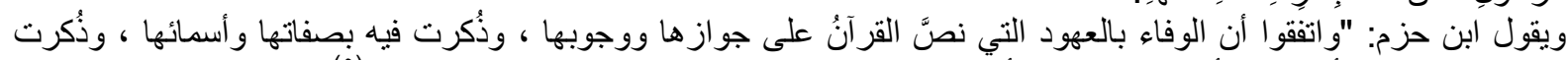

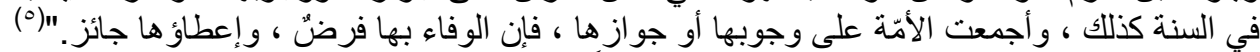

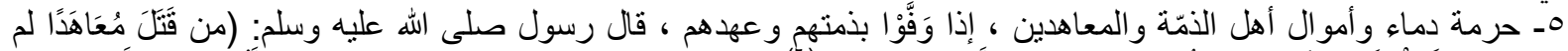

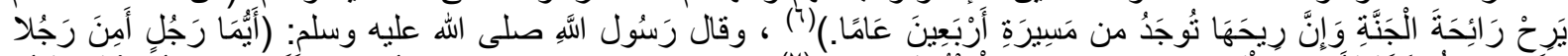

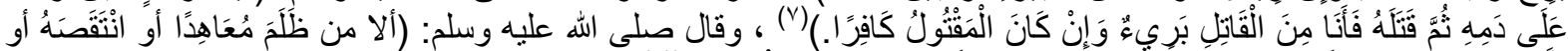

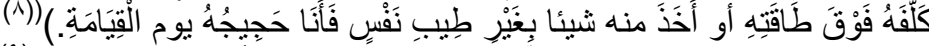

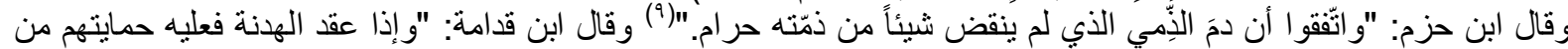

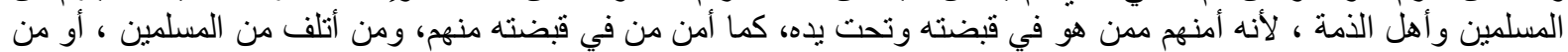

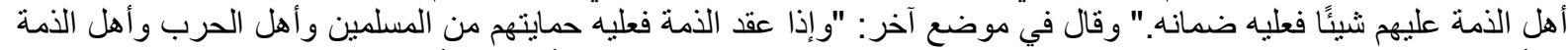

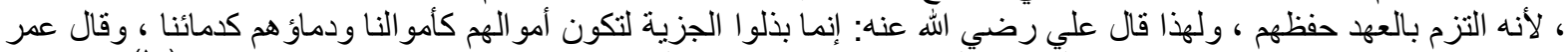

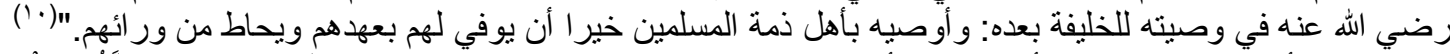

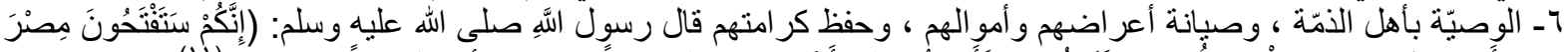

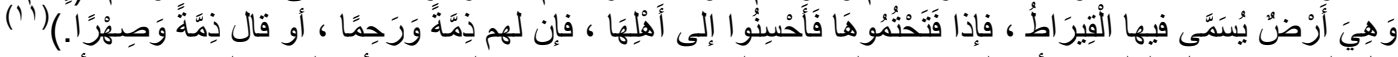

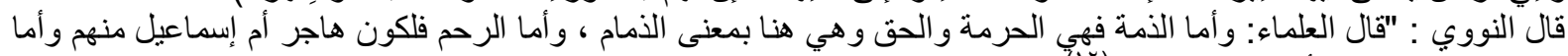

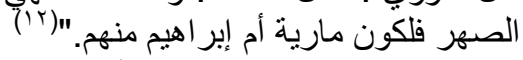

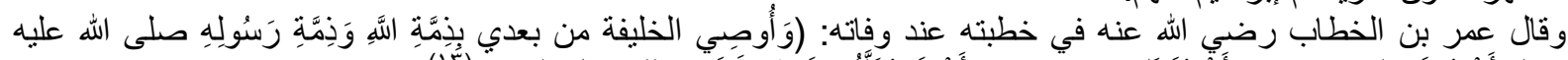

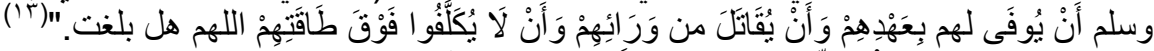

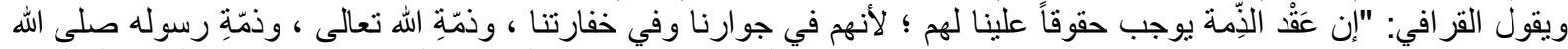

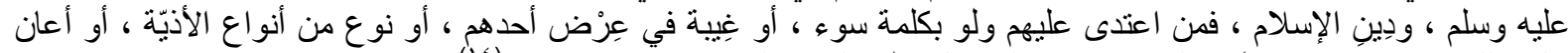

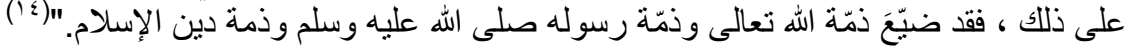

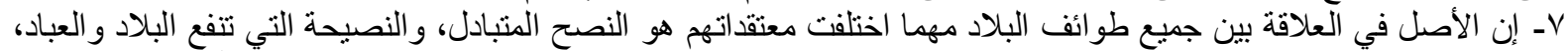

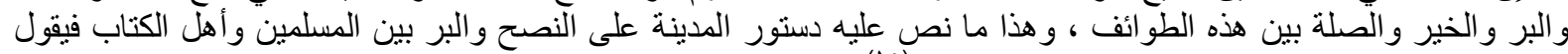

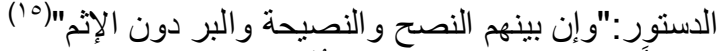

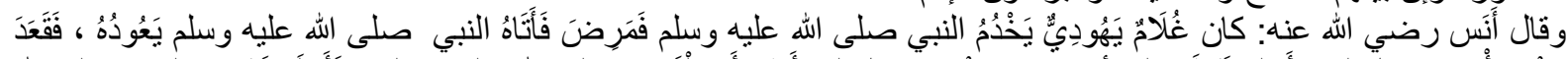

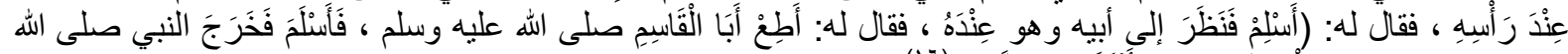

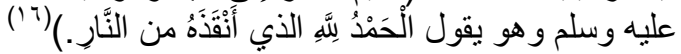

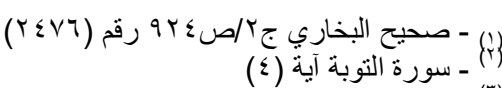

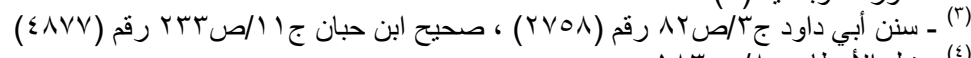

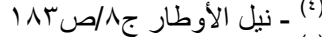

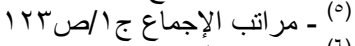

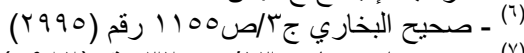

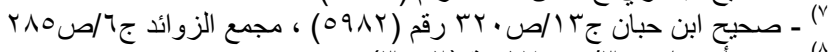

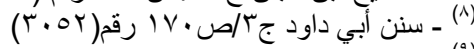

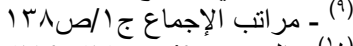
r)

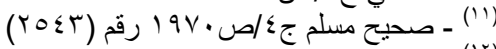

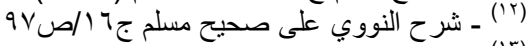

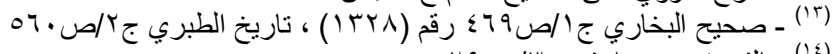

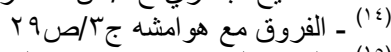

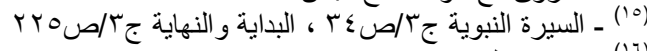

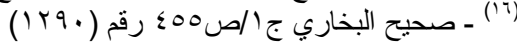




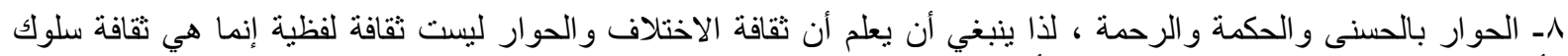

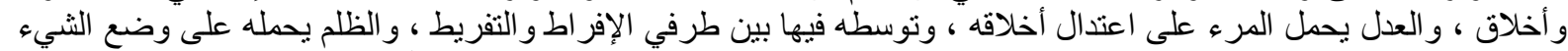

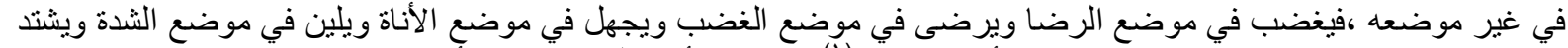

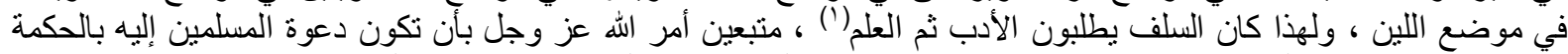

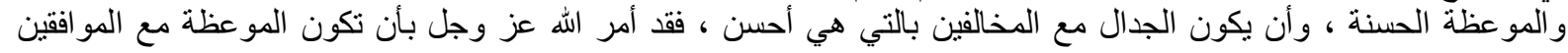

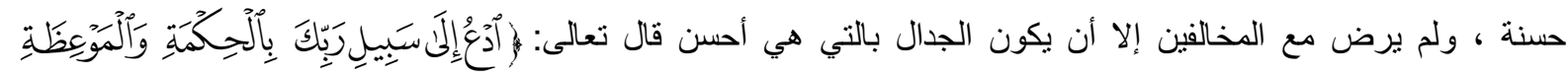

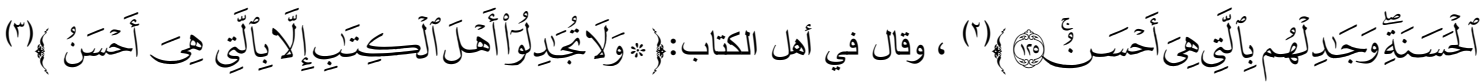

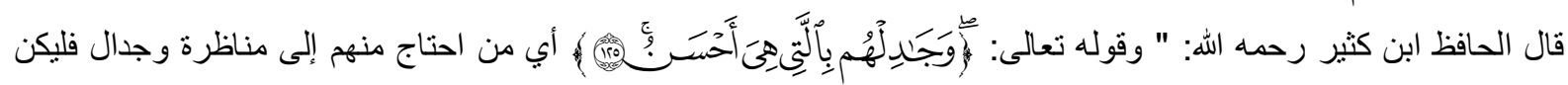

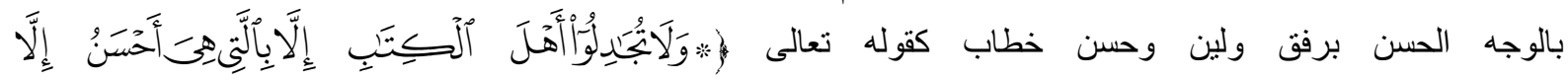

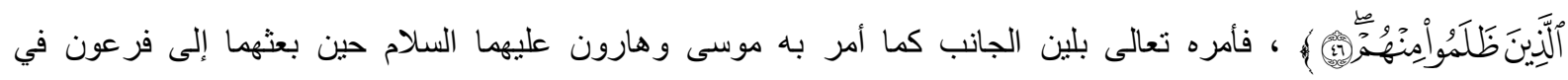

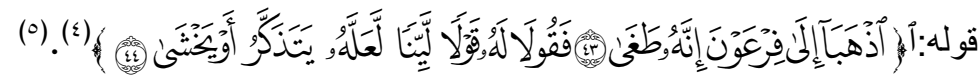

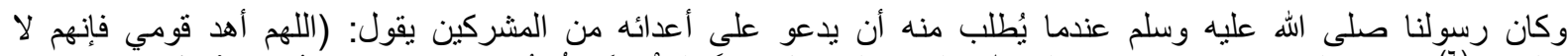

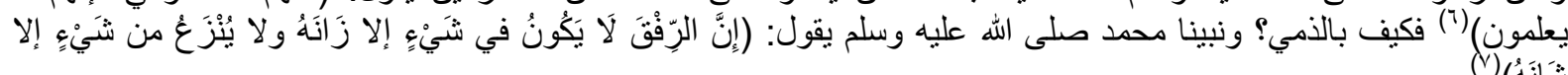

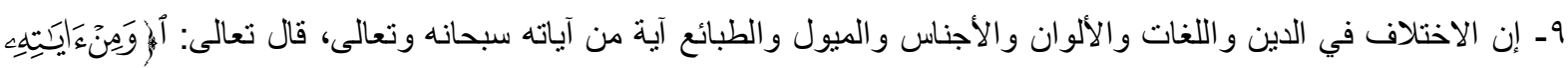

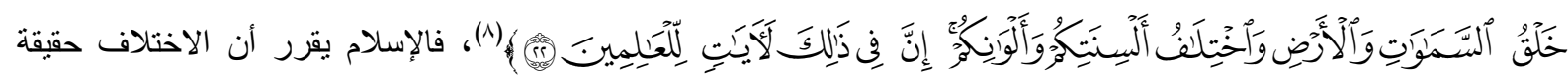

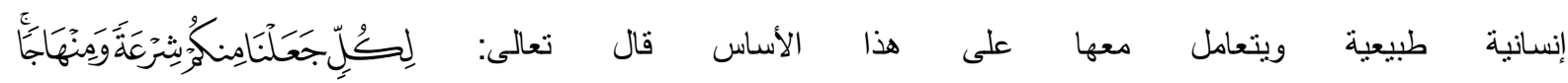

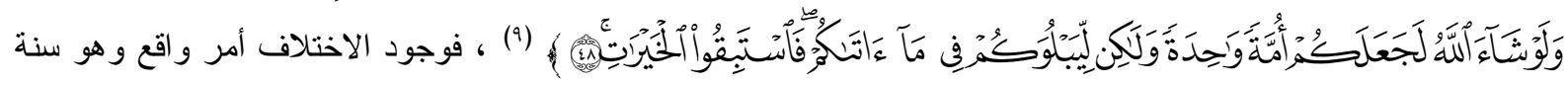

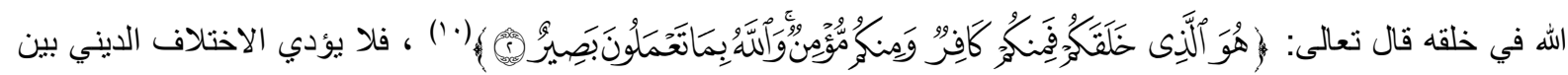

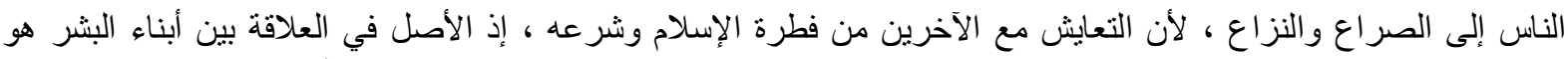

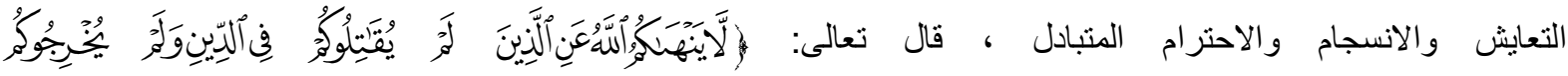

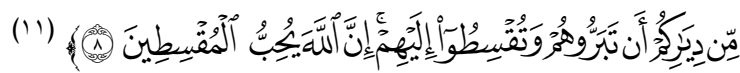

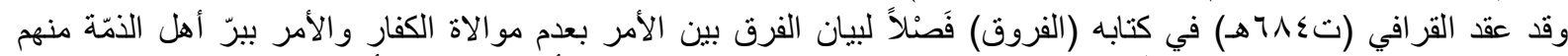

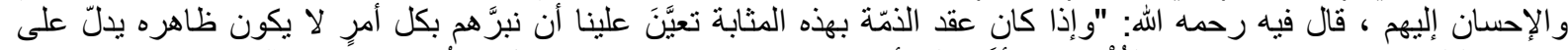

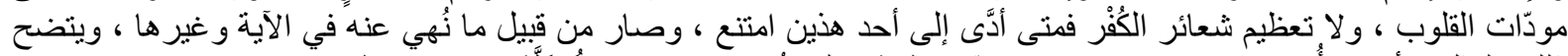

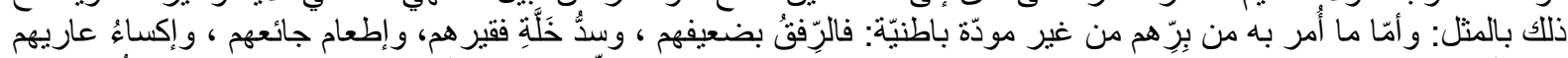

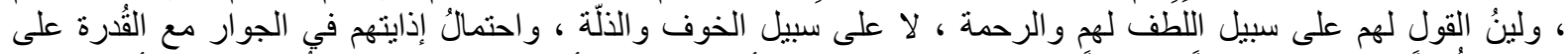

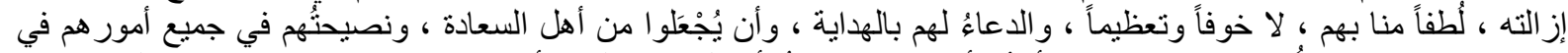

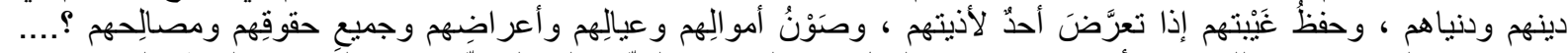

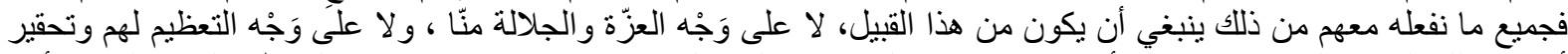
أنفسنا بذللك الصنيع لهم ، وينبغي لنّا أن نستحضر في قلونينا ما جبلو أنليه من بغضنا وتكذيب نبينا صلى الله عليه وسلم ، و وأنهم

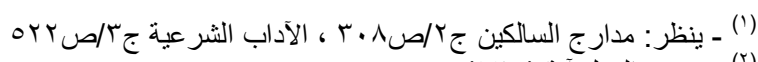

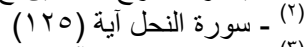

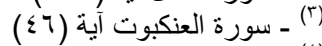

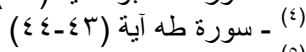

$$
\begin{aligned}
& \text { (1) }
\end{aligned}
$$

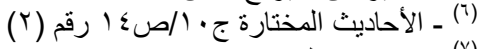

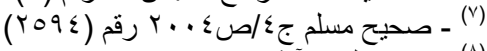

$$
\begin{aligned}
& \text { (I) }
\end{aligned}
$$

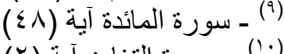

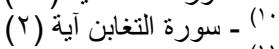

$$
\begin{aligned}
& \text { (') - (') سورة الممتحنة آية (ب-(9) }
\end{aligned}
$$


لو قدروا علينا لاستأصلو ا شأفتنا واستولو ا على دمائنا وأمو النا ، و أنهم من أنثد العصاة لربنا ومالكنا عز وجل ، ثم نعاملهم بعد

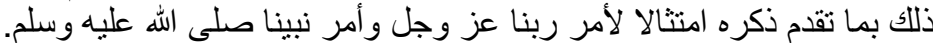

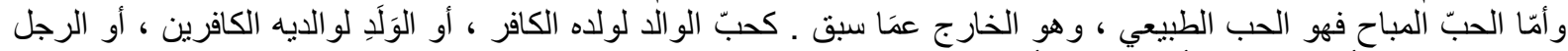

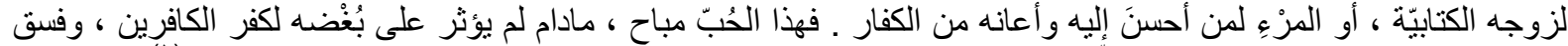

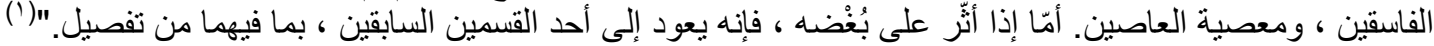

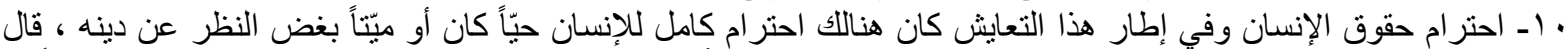

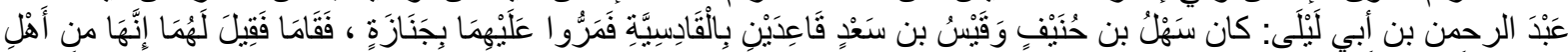

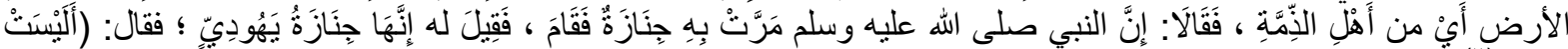

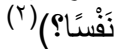

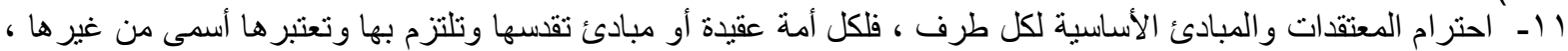
ولغير المسلمين ما يقدسونه ويحتفون به من آلهة يعبدونها ، أو مبادئ يعتزون بها ، و ومبدأ الاحتر ام مبدأ قرآني أصيل دل عليه

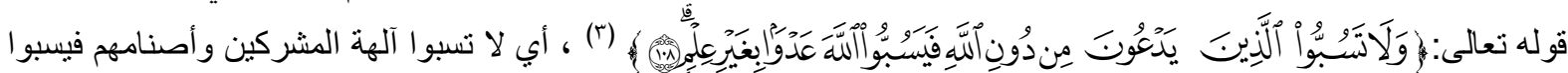
الله جهلا واعتداء لعدم معرفتهم بعظمة الله ، قال ابن عباس: يا محمد لتتنهين عن سبك آلهتنا أو لنهجون ربك فيك فنهاهم الله أن بيسبوا

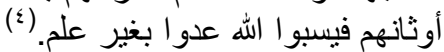

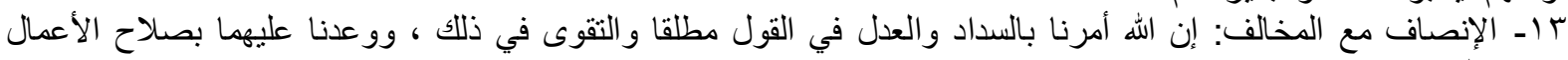

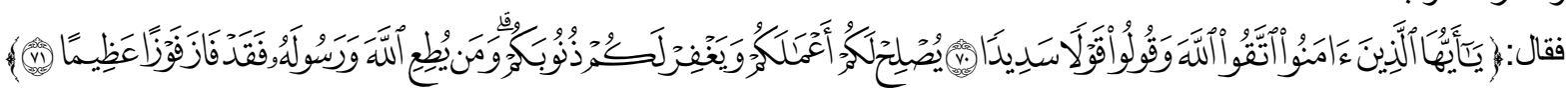

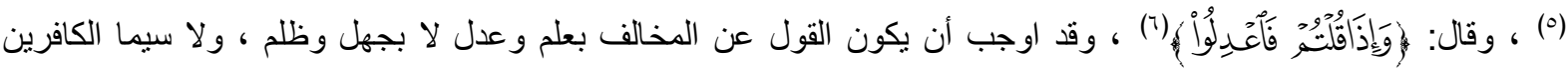
فضلا ل

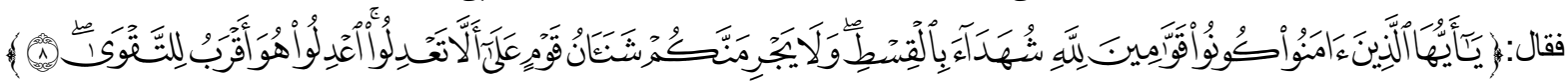

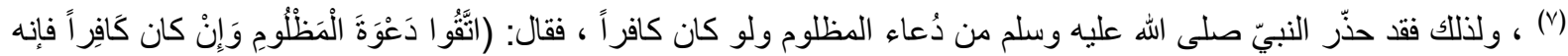

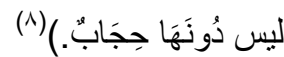
ومن تدبر القرآن الكريم وذكره لأهل الكتاب وصفاتهم الذميمة يجد أن المولى عز وجل لم يبخسهم حقهم، بل أنصفهم غاية

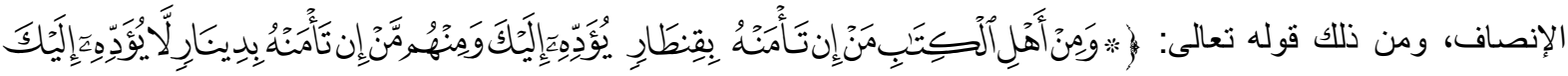

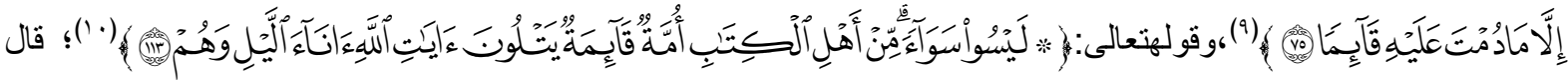

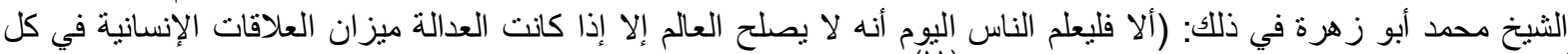

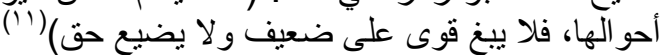

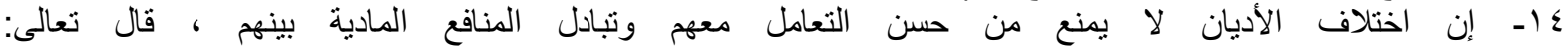

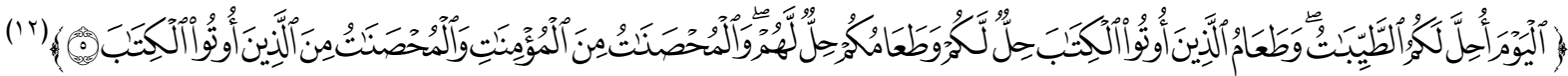

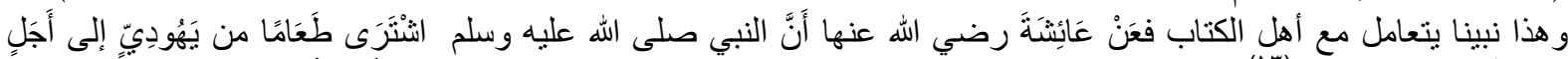

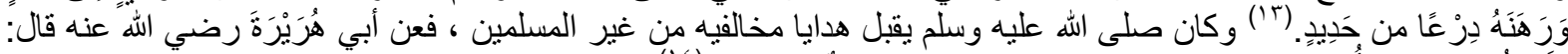

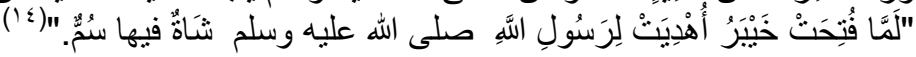

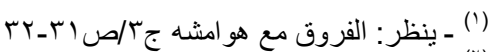

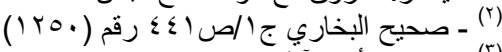

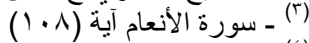

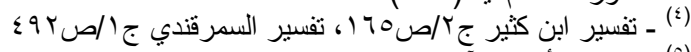

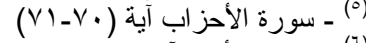

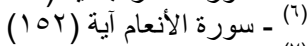

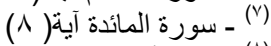

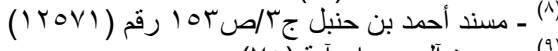

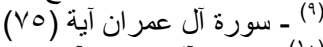

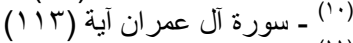

$$
\begin{aligned}
& \text { (") }
\end{aligned}
$$

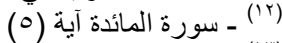

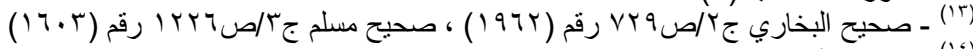


وقد قرر الفقهاء قبول الهدايا من الكفار بجميع أصنافهم حنى أهل الحرب قال في المغني : " ويجوز قبول هدية الكفار من أهل

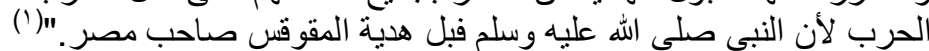

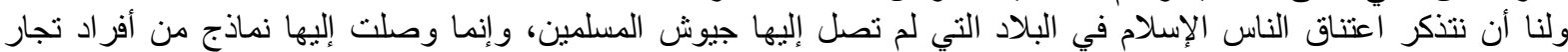

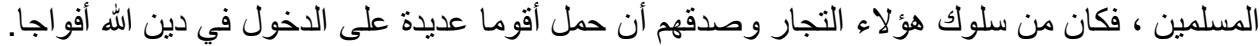

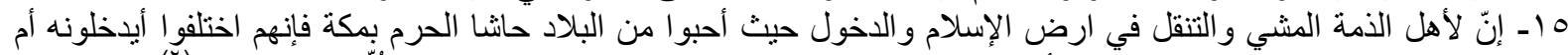

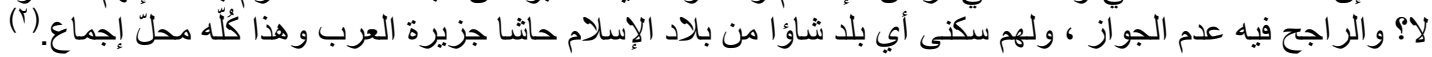

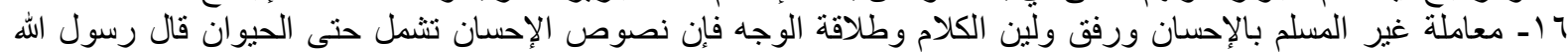

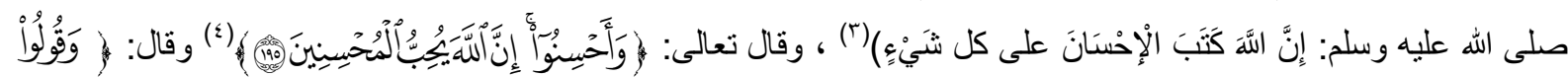

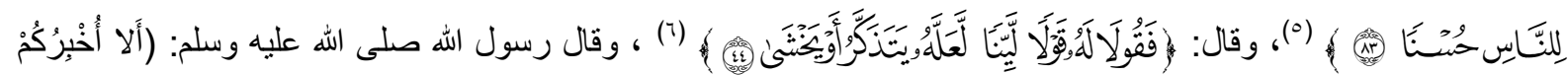

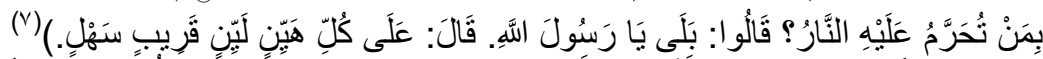

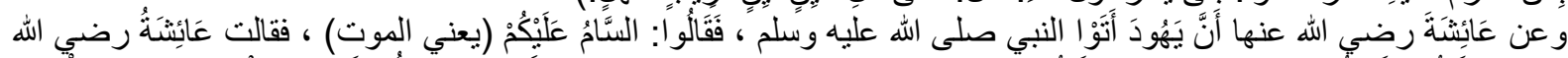

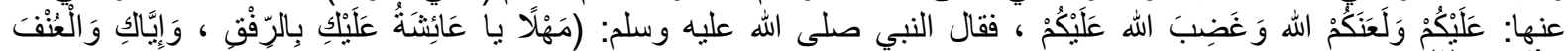

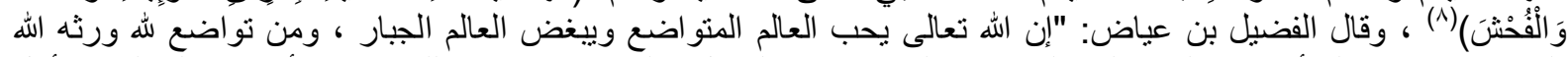

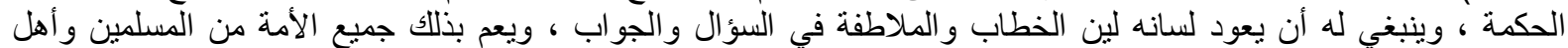

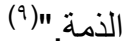

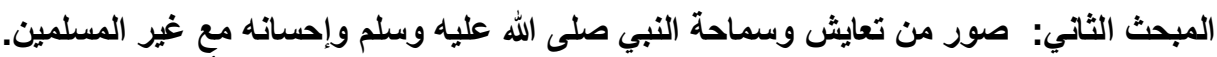

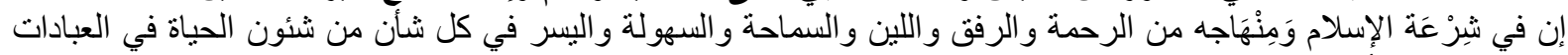

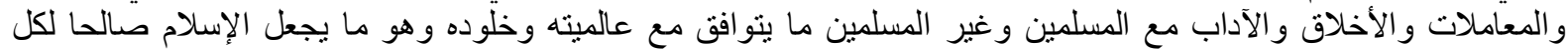

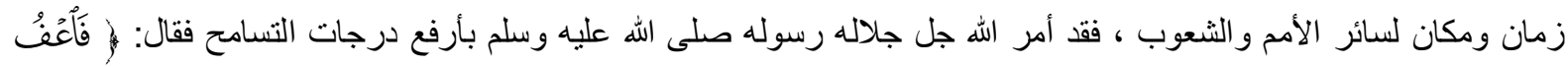

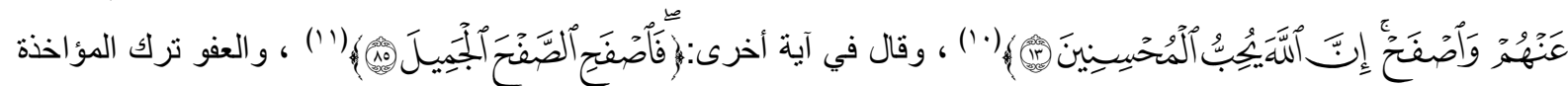

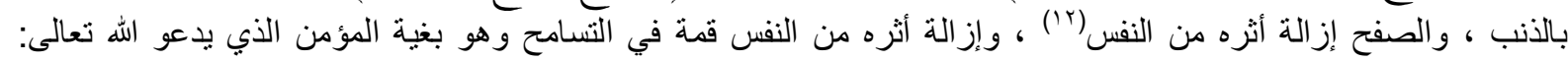

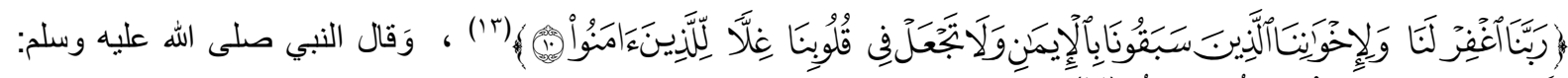

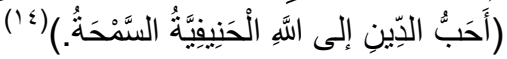

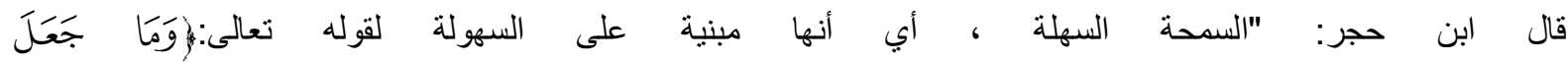

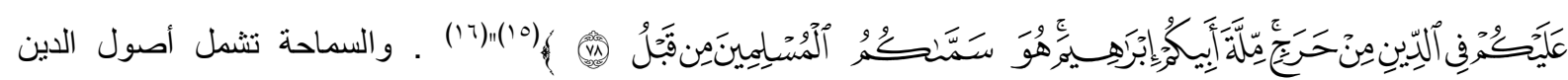

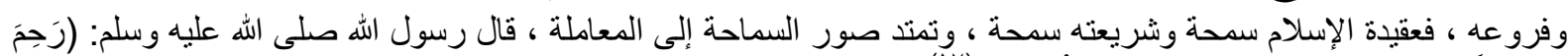

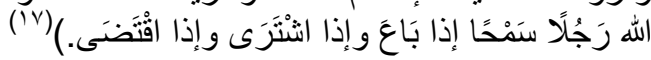

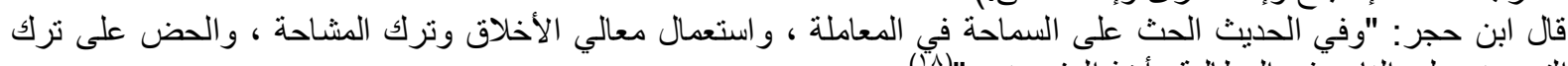

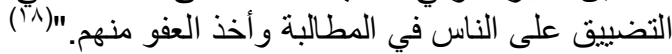

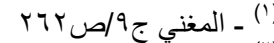

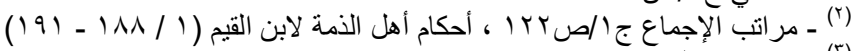

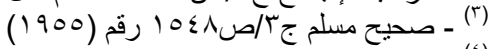

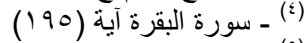

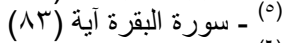

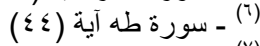

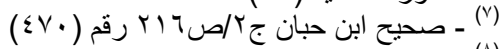

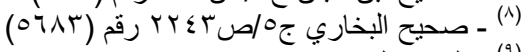

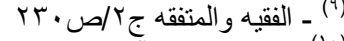

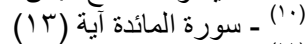

(1)

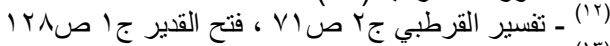

(1)

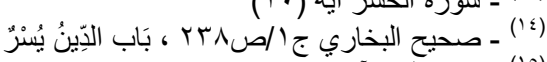

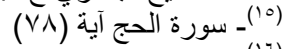

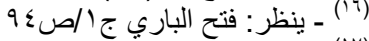

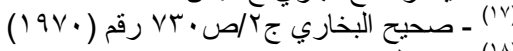

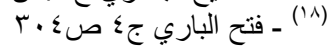


وقال جابر بن عبد الله رضي الله عنه: (كان رسول السَّهِ صلى الله عليه وسلم رَجُلًا سَهْلًا.)(') قال النووي : "أي سهل الخلق كريم

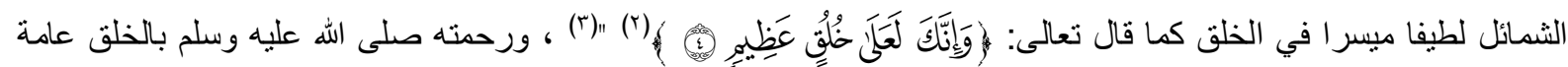

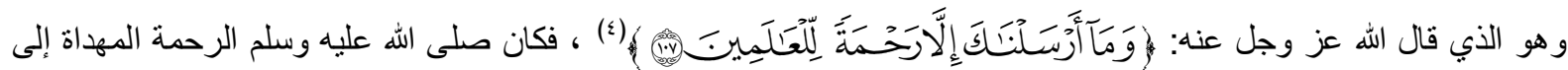

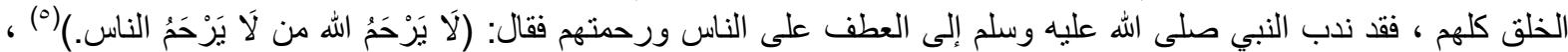

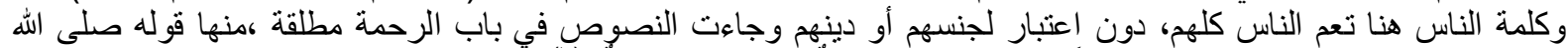

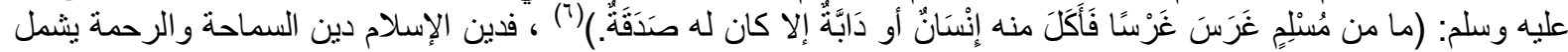

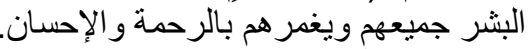

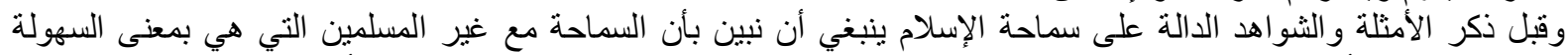
و المسامحة يجب أن تكون منضبطة بضو ابط الثررع فلا تكون بمعنى الضعف فالإسلام لا يرضى لألهانه الذّل والهوان ، و والمسلم

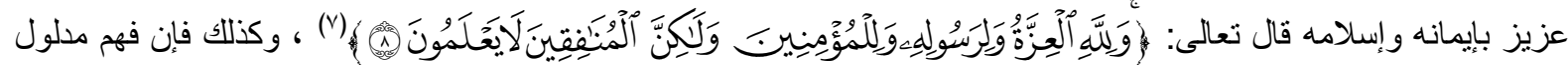

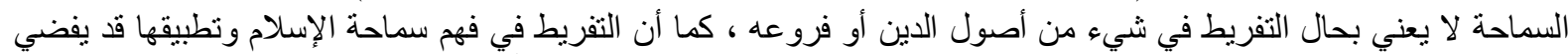

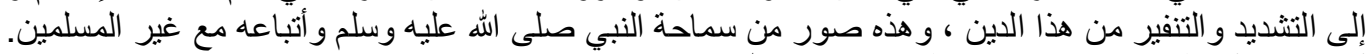

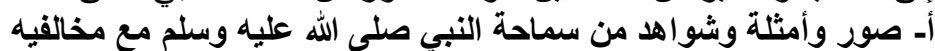

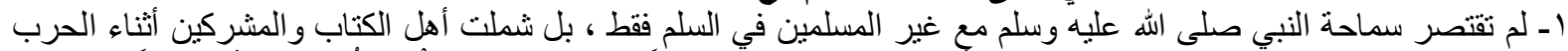

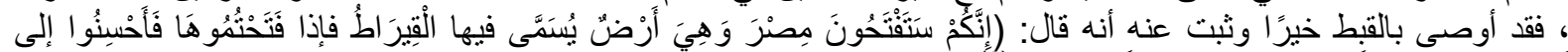

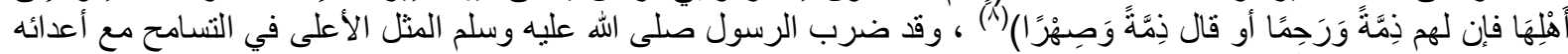

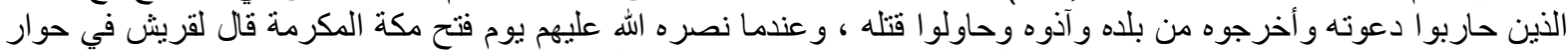

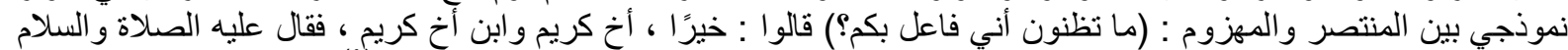

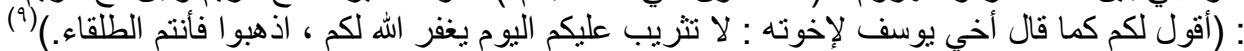

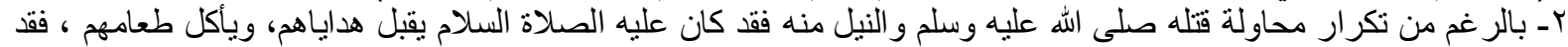

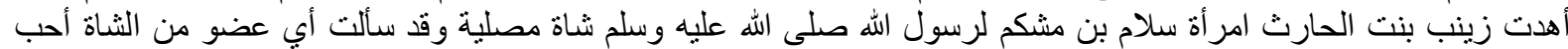

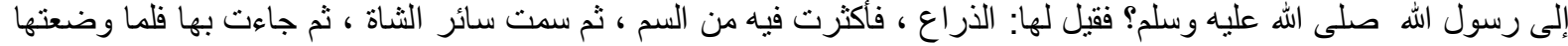

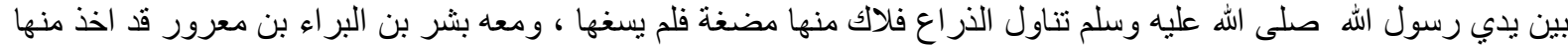

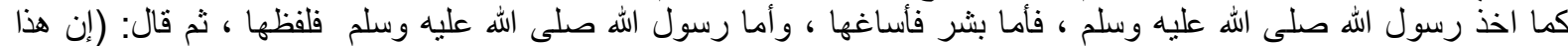

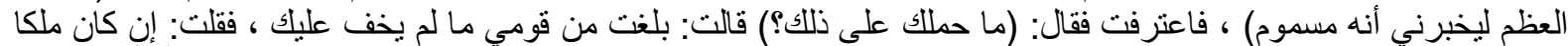

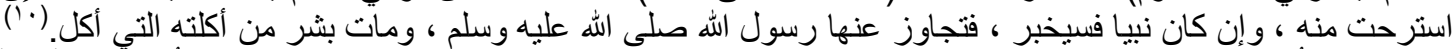

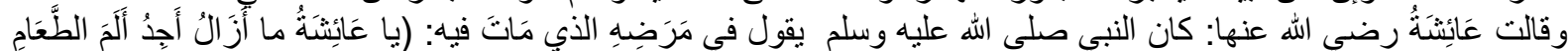

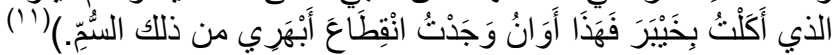

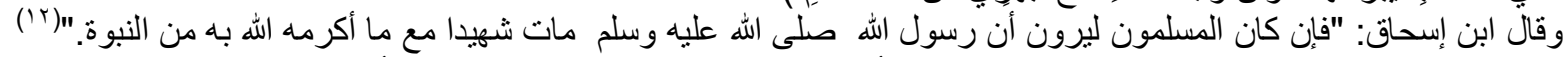

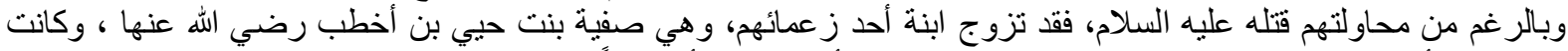

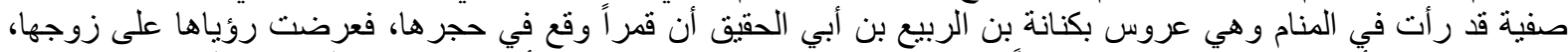

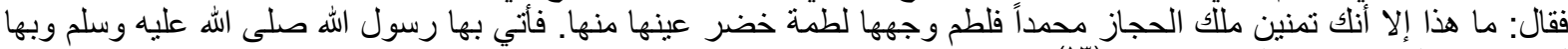

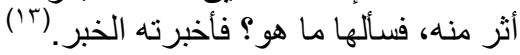

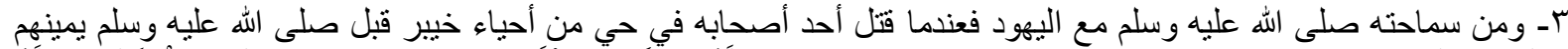

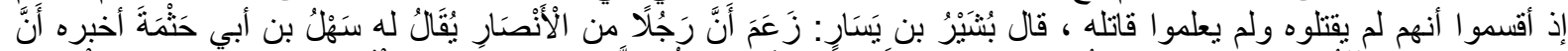

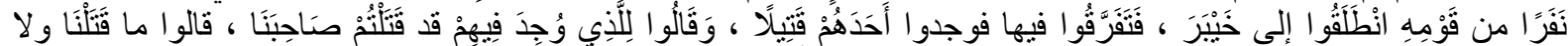

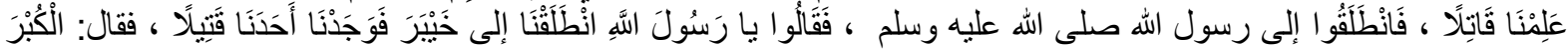

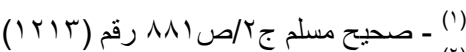

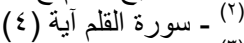

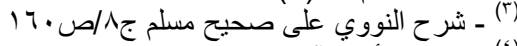

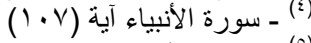

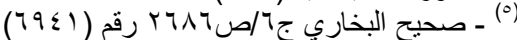

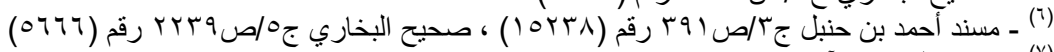

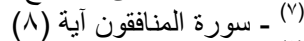

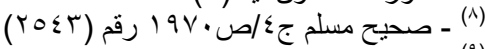

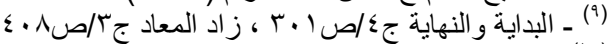

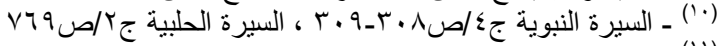

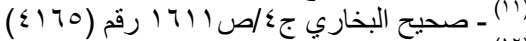

(r)

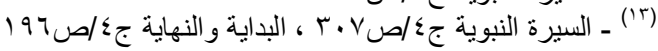




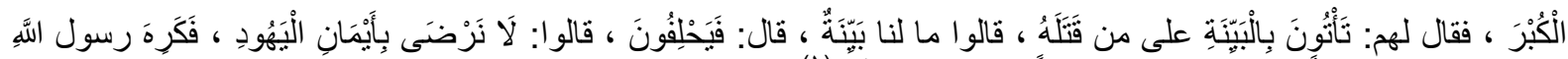

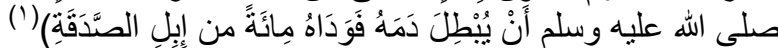

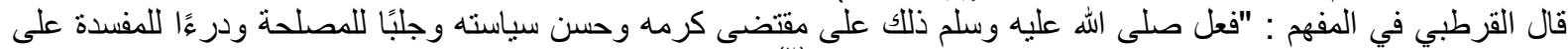

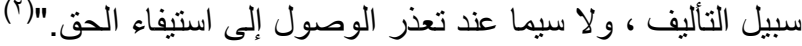

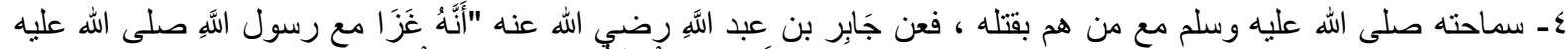

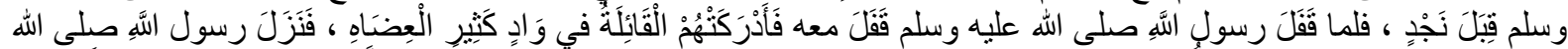

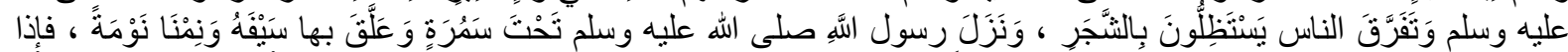

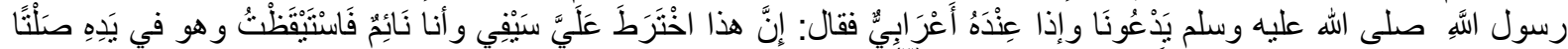

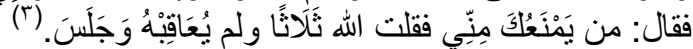

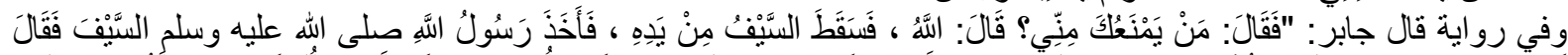

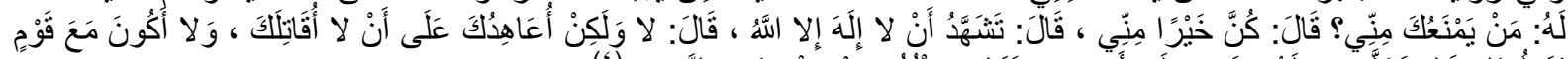

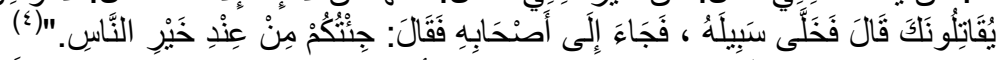

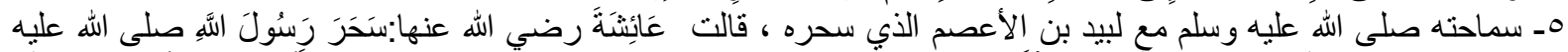

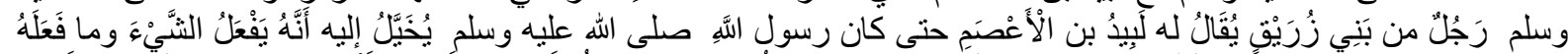

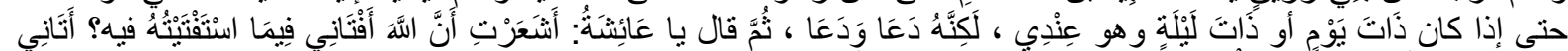

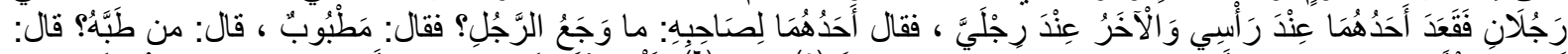

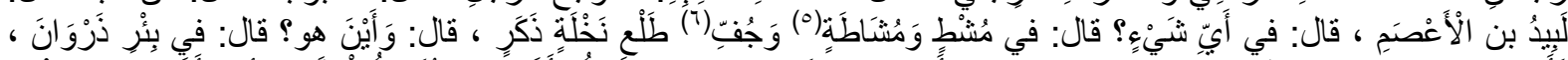

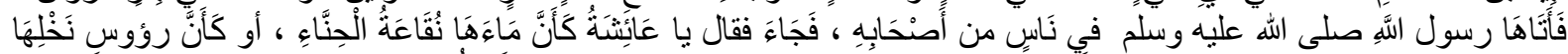

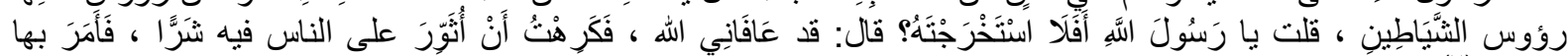

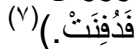

ك- تنسامح النبي صلى الله عليه وسلم مع بعض المنافقين ، فقد تحمل أذى المنافق عبد الله بن أُبي بن سلول عندما اتهم زوجته

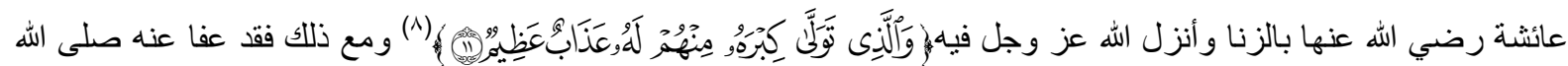

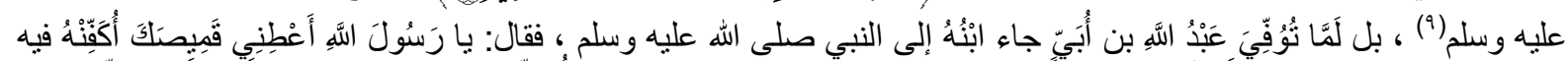

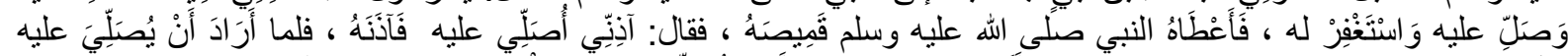

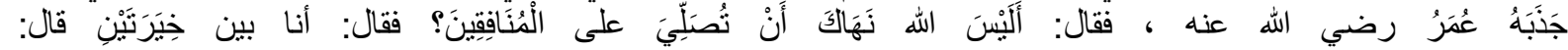

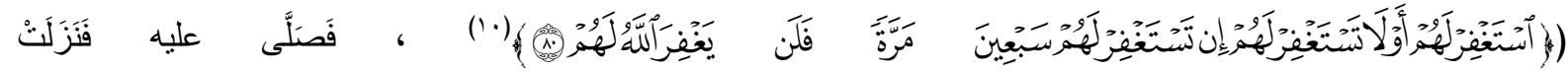

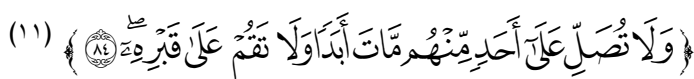

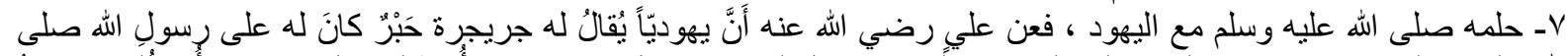

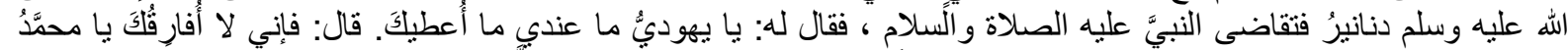

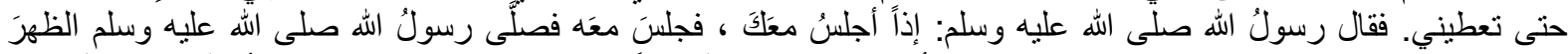

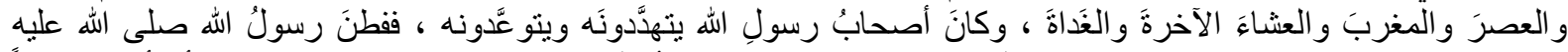

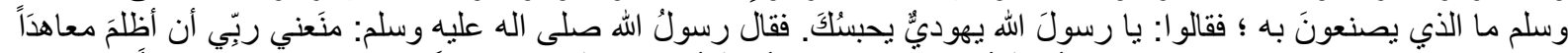

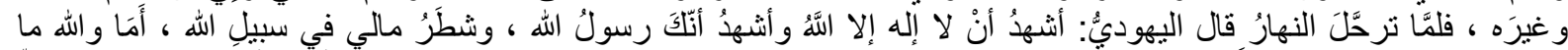

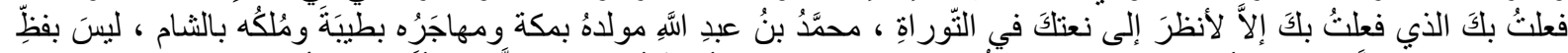

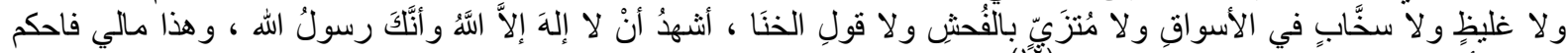

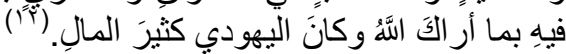

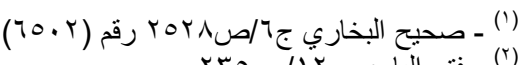

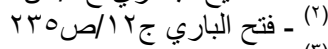

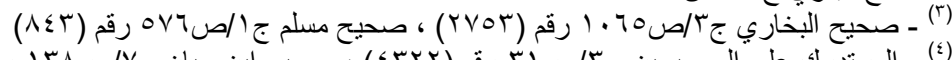

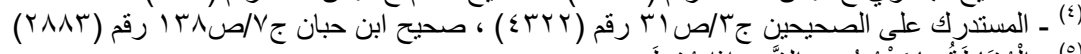

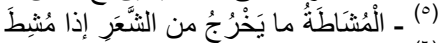

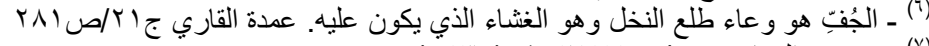

(v)

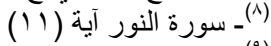

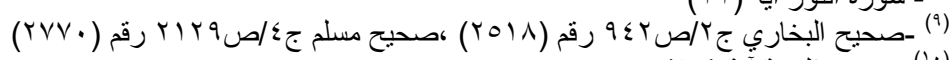

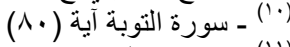

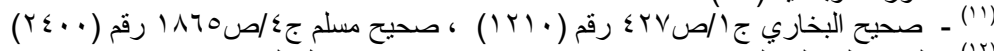

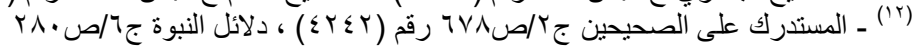




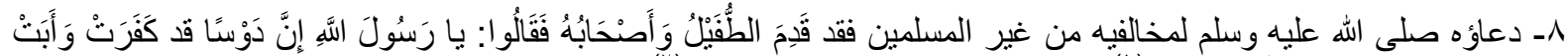

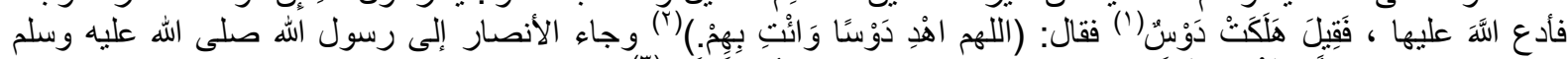

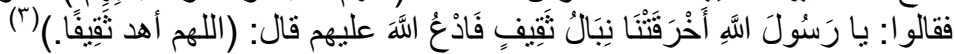

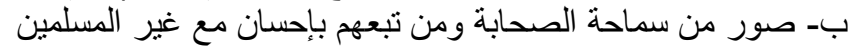

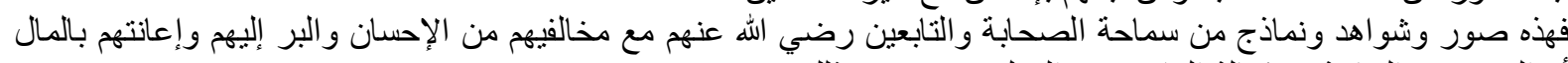

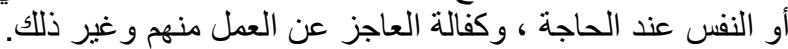

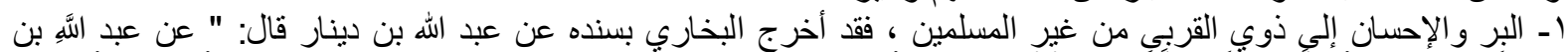

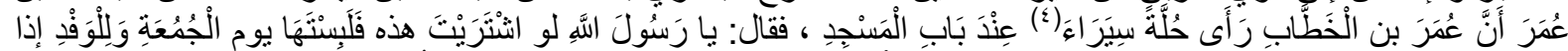

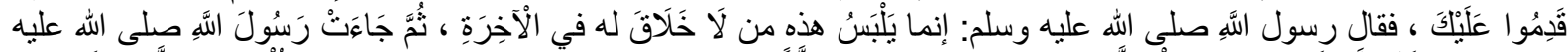

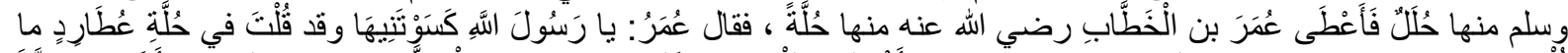

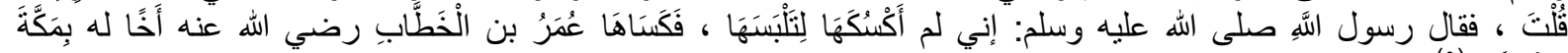

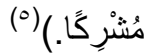

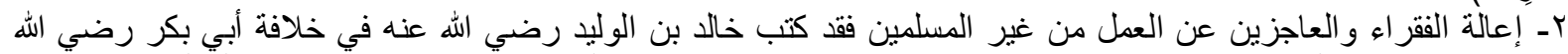

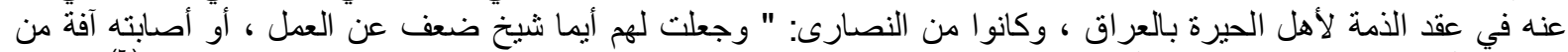

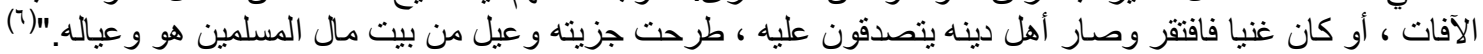

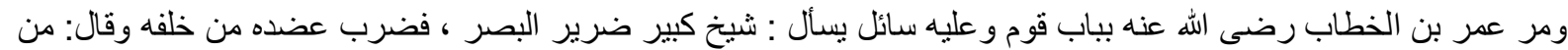

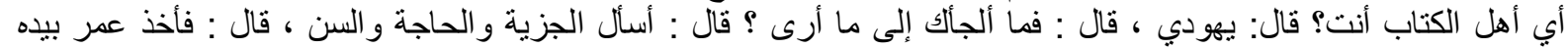
وذهب به إلى منزله فرضخ له بشيء من المنزل ثم أرسل إلى خازن بيت المال فقال : انظر هذا وأمثاله ألهال فو الله ما أنصفناه أن أكلنا

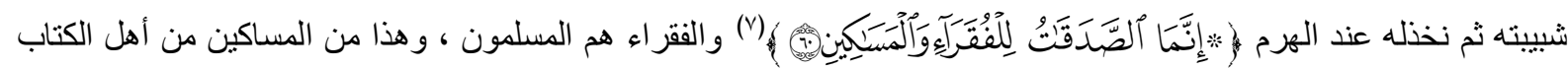

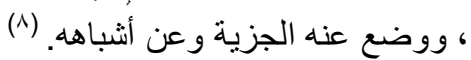

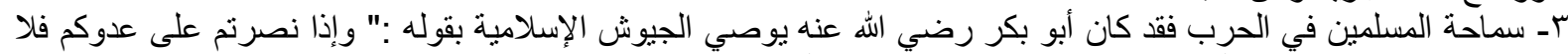

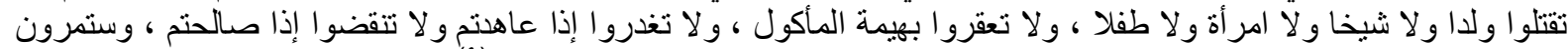

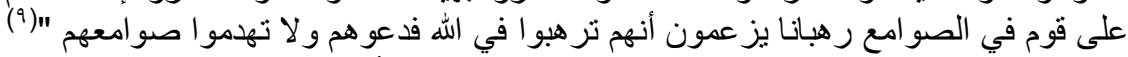

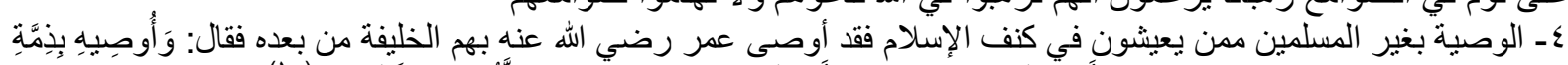

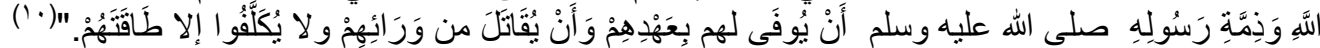

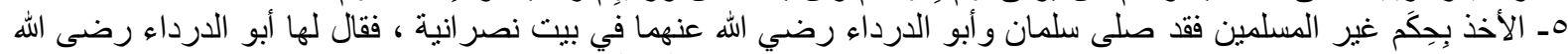

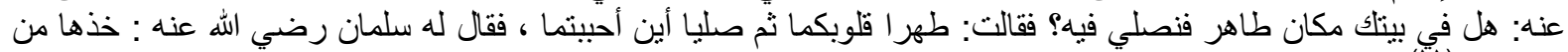

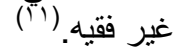

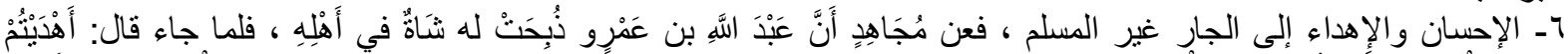

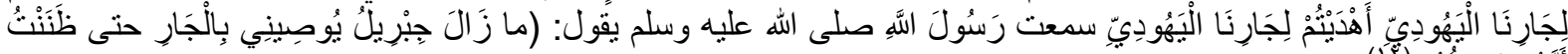

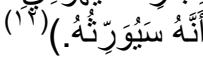

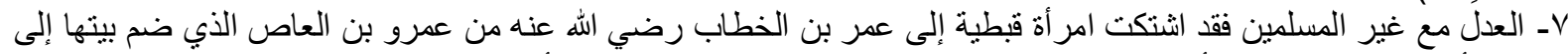

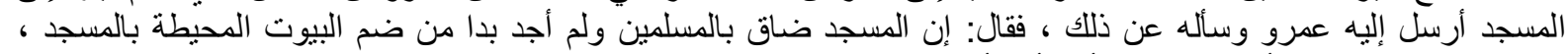

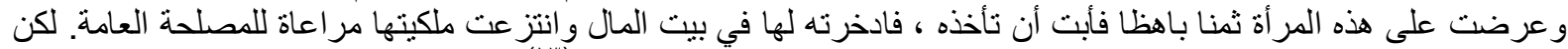

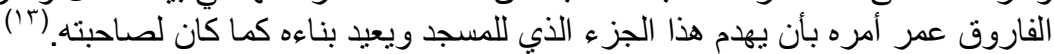

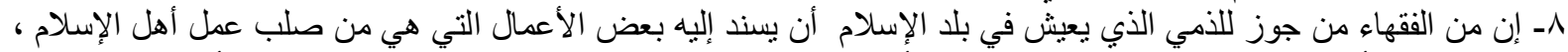

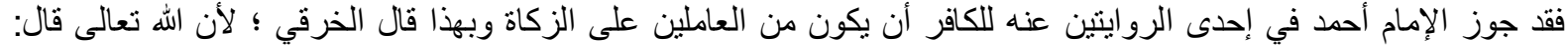

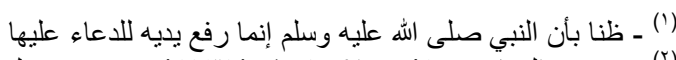

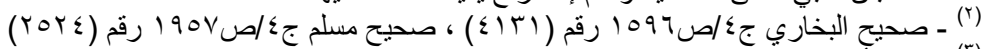

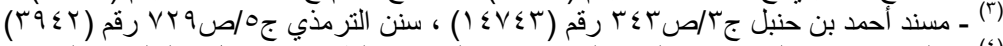

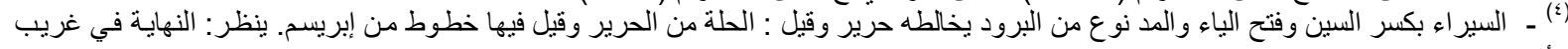

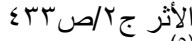

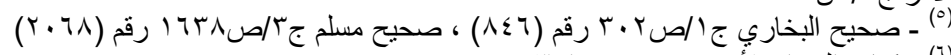

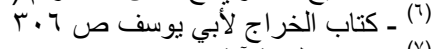

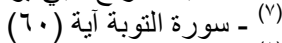

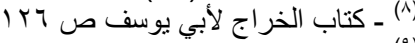

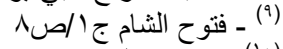

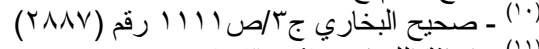

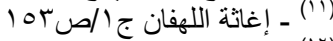

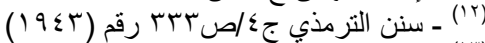

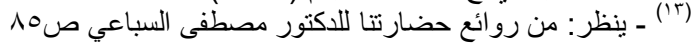




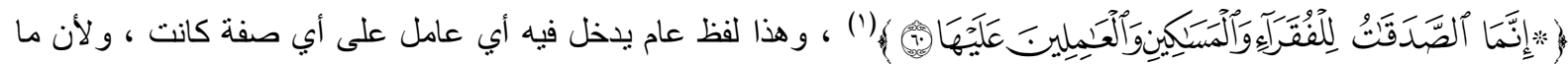

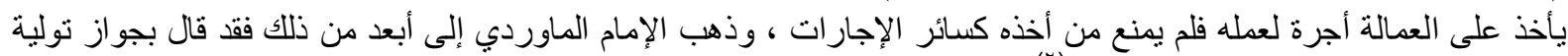

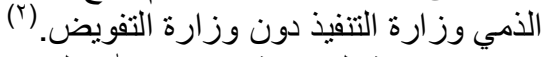

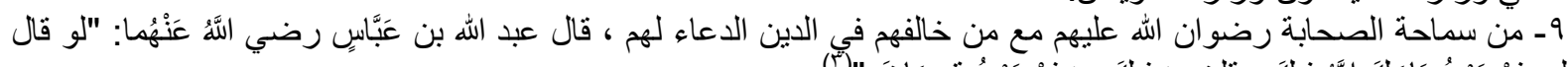

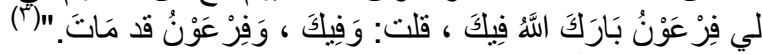

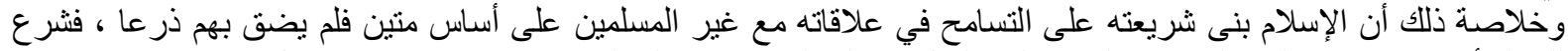

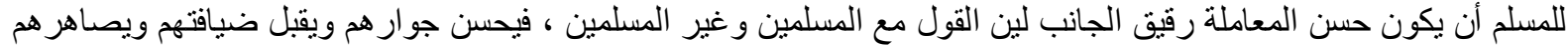

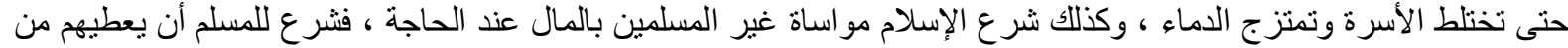

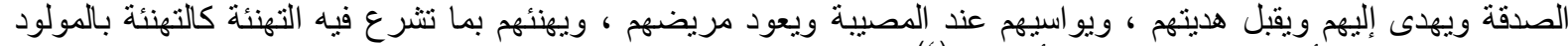

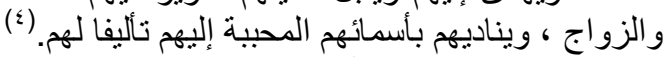

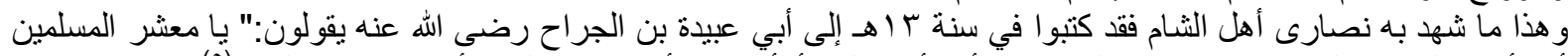

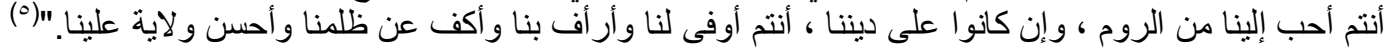
الخاتمة

الحمد لله أهل الحمد ومستحقه ، والصلاة والسلام على من فاق الناس بخلقه وخلقه ، و على آله و أصحابه الذين أخذوا الإسلام

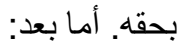

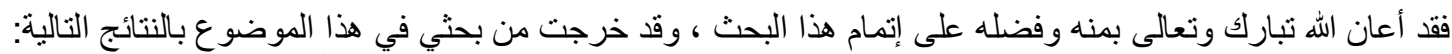

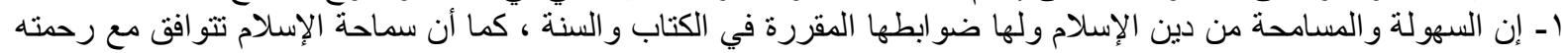
و عالميته وو اقعيته ، إذ لا يسع دين العالم كله إلا إذا كان فيه من السماحة و البسر ما بيت افق مع طبيعة البشر على اختلاف ثقافاتهم و عاداتهم. ب- وجوب فهم المدلول الثرعي لسماحة الإسلام ، لأن عدم فهها يؤدي إلى الوقوع في المحظور ، فتظهر طائفتان إحداهما

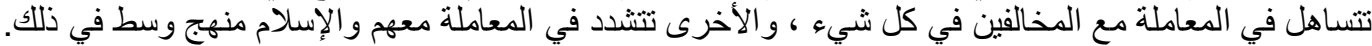
r- ليس المقصود بالتعايش أن نذيب هذا الطرف في ذاكل أو إلغاء الآخر أو محوه، ولكن كيف نتعايش بما يحترم كل منا الطرف

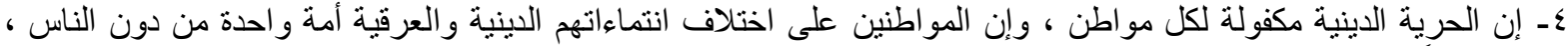

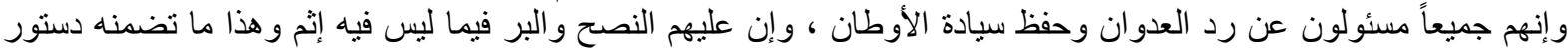
المدينة.

هـ تطبيق مبدأ حسن التعامل والحكمة في التعامل مع المخالفين في الدين ، فبه يسعد البلا ويستتب الأمن ، ويسلم من الانهيار

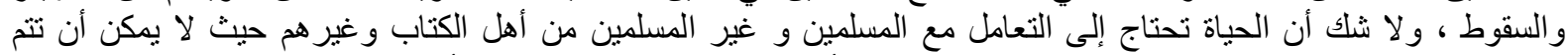

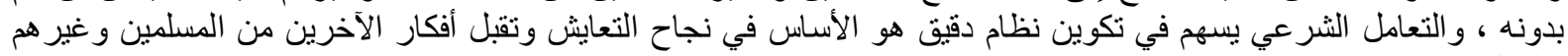

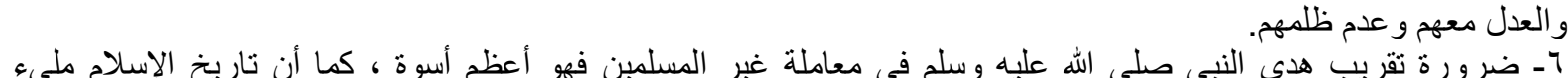

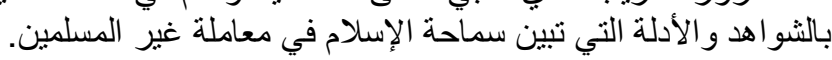
لـ بيان فقه معاملة غير المسلمين وبيان سماحة الإسلام عبر وسائل الإعلام و المحاضر الات و الندوات و والخطب و المو اعظ.

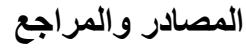

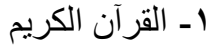
r أ- الأحاديث المختارة: أبو عبد الله محمد بن عبد الواحد بن أحمد الحنبلي المقدسي ، تحقيق: عبد الملك بن عبد الله بن دهيش ،

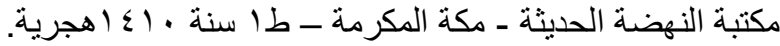

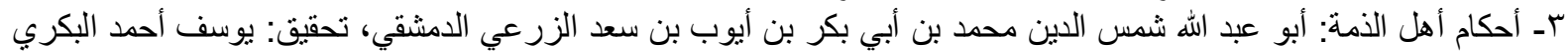

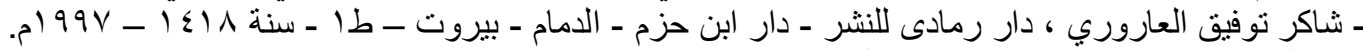

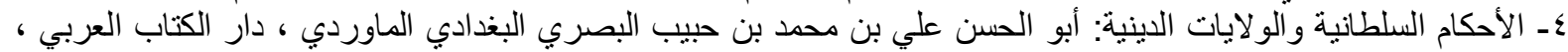

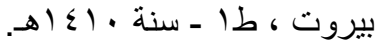
هـ الآداب الثرعية والمنح المرعية: الإمام أبو عبد الله محمد بن مفلح المقدسي ، تحقيق: شعيب الأرنؤوط / عمر القيام ،

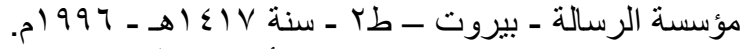
آ- إعلام الموقعين عن رب الروب العالمين: أبو عبد الله شمس الدين محمد بن أبي بكر بن أيوب بن سعد الزرعي الدمشقي ، تحقيق: طه

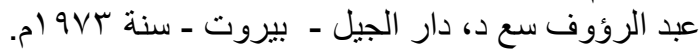

(7.) - (1) - سورة التوبة (1)

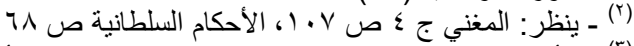

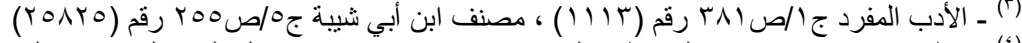

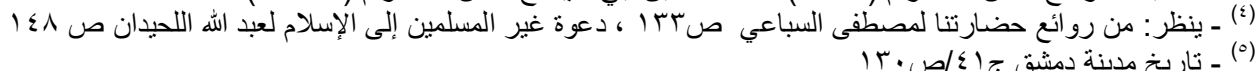


V- إغاثة اللهفان من مصائد الثنيطان: محمد بن أبي بكر أيوب الزرعي أبو عبد الله، تحقيق: محمد حامد الفقي ، دار المعرفة -

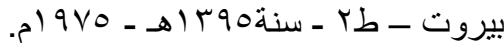

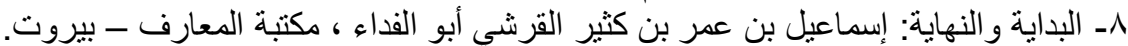

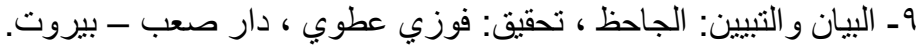

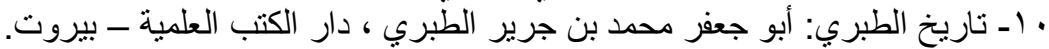

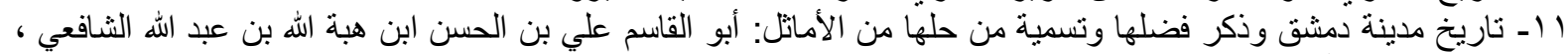

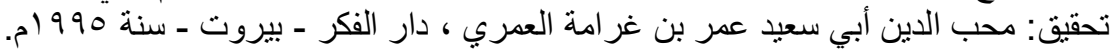

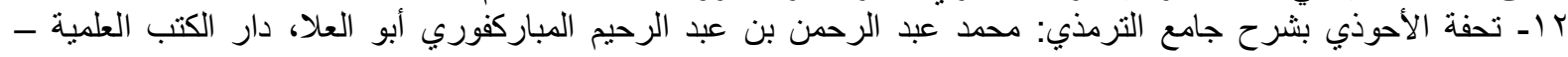

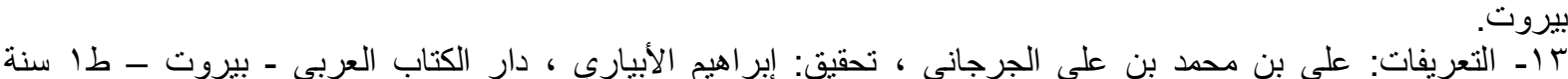

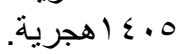

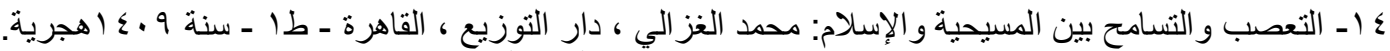

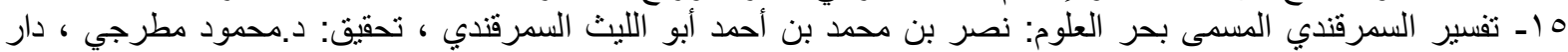
الفكر - بيروت 7 الفير ـ تفسير الطبري المسمى (جامع البيان عن تأويل آي القرآن): محمد بن جرير بن يزيد بن خالد الطبري أبو جعفر، دار الفكر -

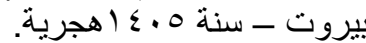

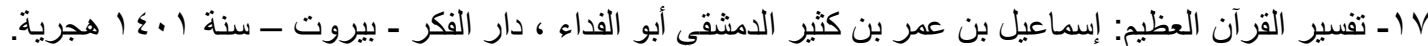

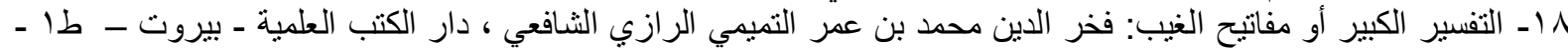

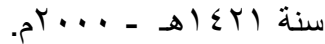

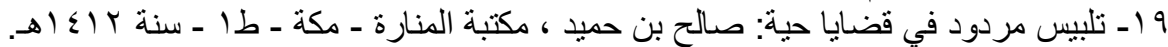

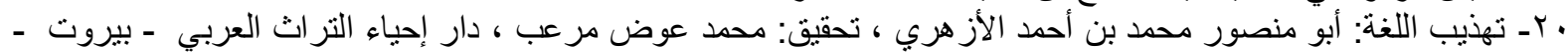

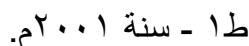

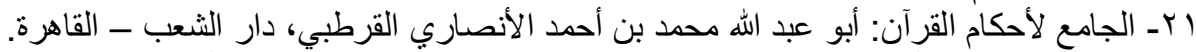

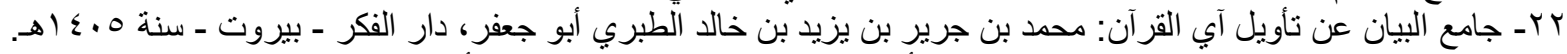

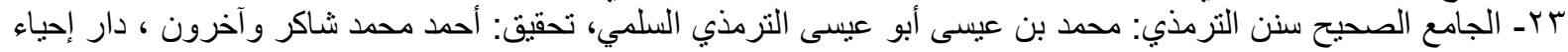

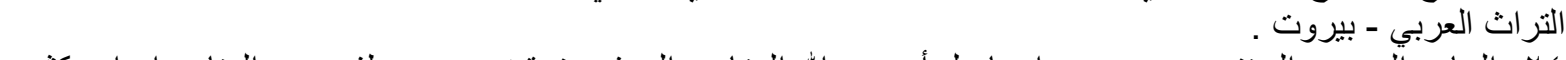

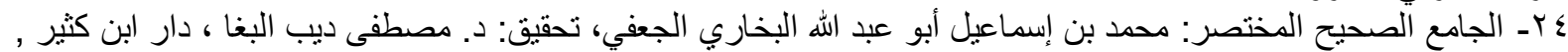

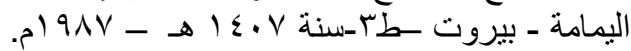

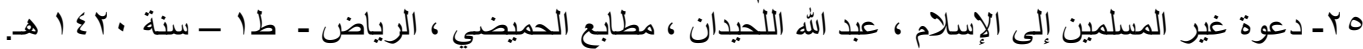

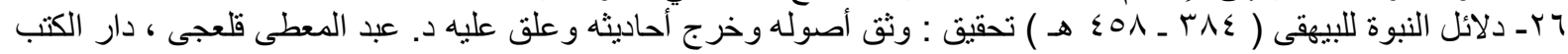

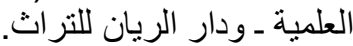

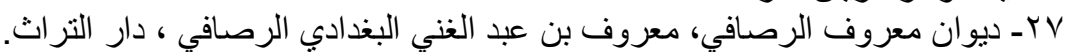

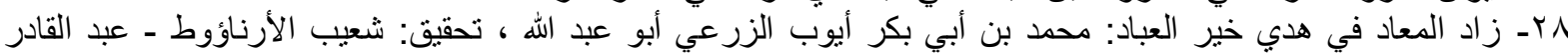

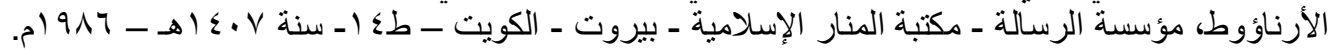

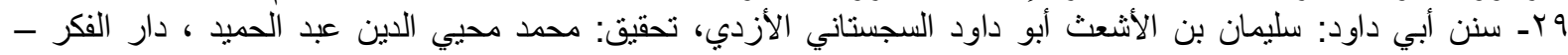

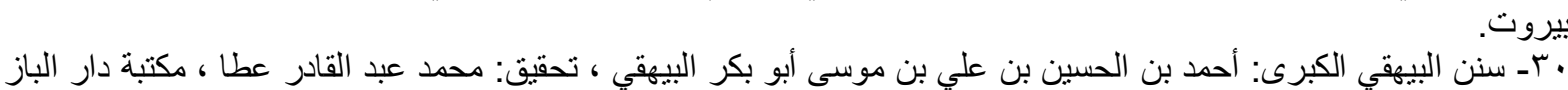

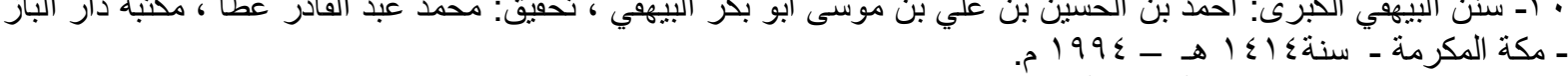

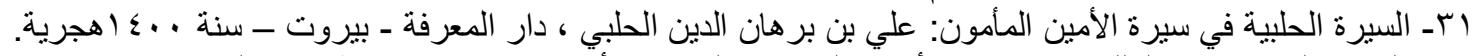

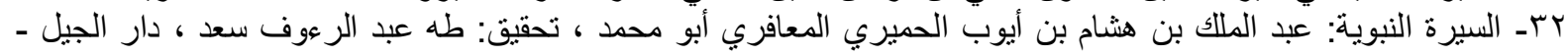

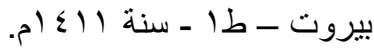
بـــ شرح النووي على صحيح مسلم: أبو زكريا يحيى بن شرف بن مري النووي، دار إحباء التراث العربي - بيروت ـ طr( - D ـ ــ صحيح ابن حبان: محمد بن حبان بن أحمد أبو حاتم التميمي البستي، تحقيق: شعيب الأرنؤوط ، مؤسسة الرسالة - بيروت ـ

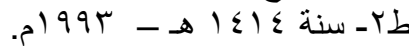
هب- صحيح مسلم: مسلم بن الحجاج أبو الحسين القشيري النيسابوري، تحقيق: محمد فؤاد عبد الباقي ، دار إحباء التراث العربي

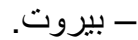

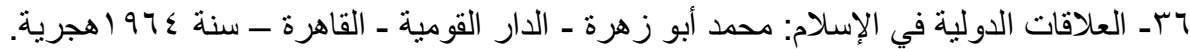

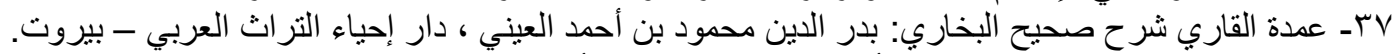

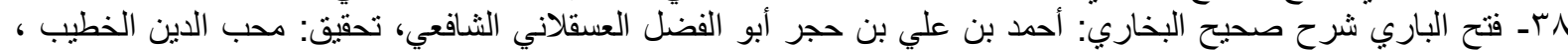

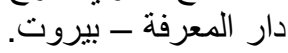
و بـ فتح القدير الجامع بين فني الرواية و الدراية من علم التفسير: محمد بن علي بن محمد الثوكاني ، دار الفكر - بيروت. 


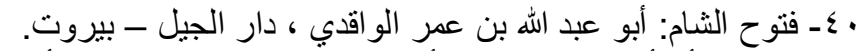

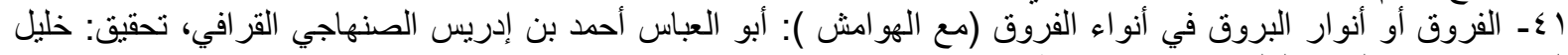

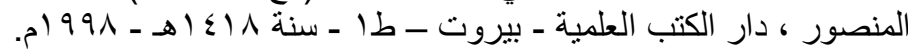

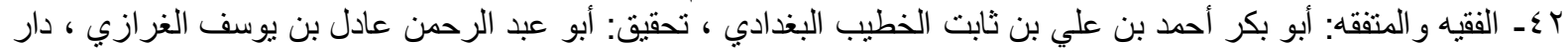

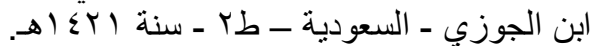

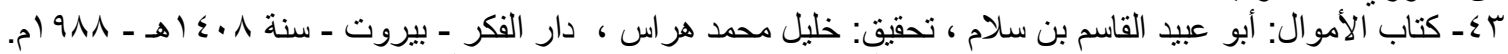

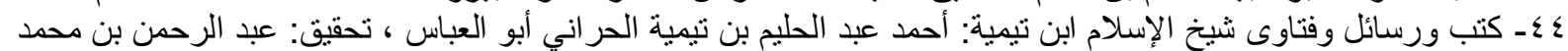

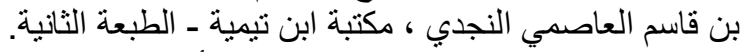

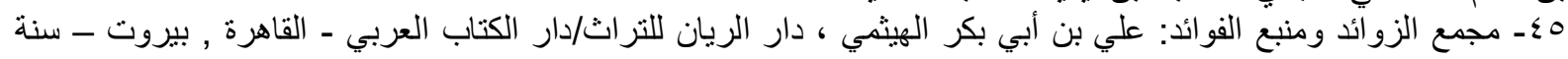
( كـ ــ محاضر اته الأدباء ومحاورات الثعر اء و البلغاء: أبو القاسم الحسين بن محمد بن المفضل الأصفهاني ، تحقيق: عمر الطباع،

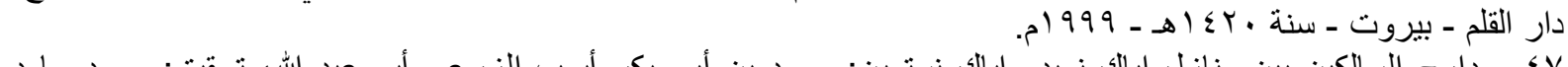

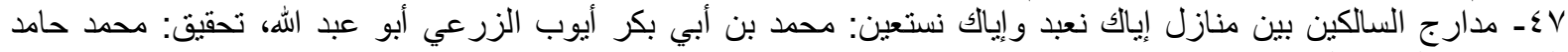

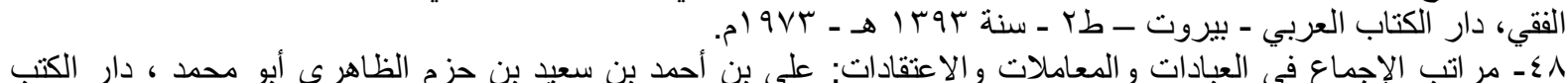
يـ ــ مراتب الإجماع في العبادات والمعاملات والاعتقادات: علي بن أحمد بن سعيد بن حزم الظاهري أبو محمد ، دار الكتب

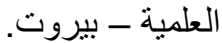
9 § ــ المستدرك على الصحيحين: محمد بن عبد الله أبو عبد الله الحاكم النبسابوري ، تحقيق: مصطفى عبد القادر عطا ، دار الكتب

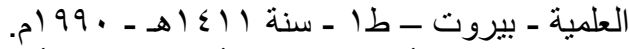

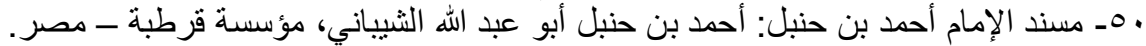

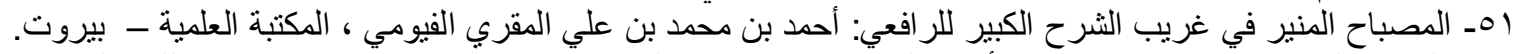

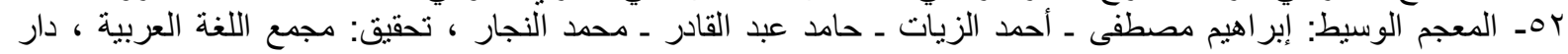

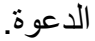
بهـ المغني في فقه الإمام أحمد بن حنبل الثنيباني: عبد الله بن أحمد بن قدامة المقدسي أبو محدد ، دار الفكر - بيروت ـ طاـ

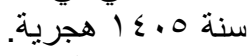

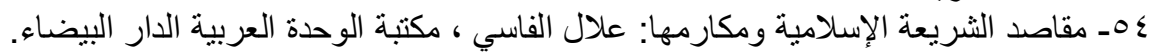

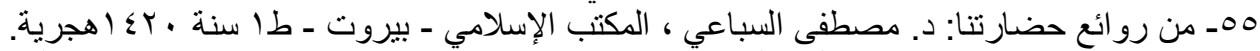

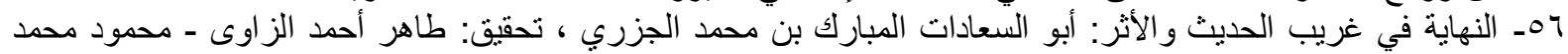

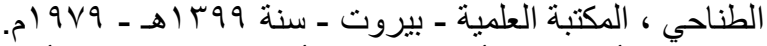
Vوـ نيلّ الأوطار من أحاديث سيد الأخيار شرح منتقى الأخبار : محمد بن علي بن محمد الثوكاني، دار الجيل ـ بيروت ـ سنة

\section{Abstract}

Islamic law has come to the benefit of the slaves in the pension and return, and has organized the Muslim relationship to Allah and his relationship with others, and this is a comprehensive Islamic approach to all transactions, whether economic, social or cultural, and the general purpose of Islamic law is the architecture of the land and the preservation of the system of citizenship and coexistence.

And in light of the plurality and intellectual pluralism of the world, which may be in one society, we find it urgent to show that Islam is a part of non-Muslims rights under the social and social system.

This proves that it is an integrated and valid system in every place and time and that it guarantees the rights of the people in general.

The research came to show the above by emphasizing the tolerance of Islam and urging it to be a citizen and peaceful coexistence with non-Muslims. This coexistence has elements that were mentioned in the texts of Islamic law, and Muslims have turned them into reality that cannot be denied or questioned.

Keywords: Islamic law, non-Muslims rights, the tolerance. 